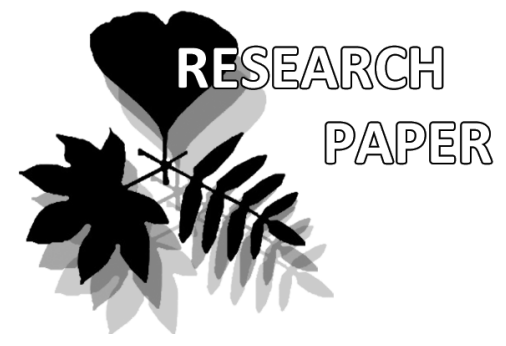

Natalia E. Koroleva

e-mail: flora012011@yandex.ru

Polar-Alpine Botanical Garden-Institute, Kirovsk, Russia

Manuscript received: 25.08.2014

Review completed: 03.02.2015

Accepted for publication: 12.02.2015

Published online: 20.04.2015

\section{Survey of Dryas octopetala - dominated plant communities in the European and North-West-Siberian Arctic}

\author{
Natalia E. Koroleva
}

\begin{abstract}
A B S T R A C T
18 associations of Dryas octopetala-dominated communities, which belong to 3 classes and 4 alliances, were observed in the European Arctic and in northwestern Siberia. Syntaxonomical differentiation is linked with the ecogeographical and floristical division of the Arctic: alliance Kobresio-Dryadion of Carici rupestrisKobresietea bellardii has its main distribution in European arctic and typical tundra and in the oroarctic belt of mountains, whilst the area of alliance Dryado octopetalae-Caricion arctisibiricae lies in the southern and typical tundra and oroarctic belt on the north of Pechora Plain, in theYugorskii Peninsula, Pay-Khoy Mts. and Polar Ural. Dryas octopetala-dominated communities lacking characteristic species of Carici rupestris-Kobresietea bellardii have been related to the alliance CassiopoSalicion herbaceae (Salicetea herbaceae) and alliance Loiseleurio-Diapension (LoseleurioVaccinietea). In the latter a suballiance Salicenion nummulariae has been proposed comprising xero-, achyonophytic communities on sandy and gravelly substrata in the southern and typical tundra of the north-east of European Russia. A synoptical table is provided.

Ke ywo rds: Braun-Blanquet, Dryas octopetala-dominated communities, European Arctic, north-western Siberia, Carici rupestris-Kobresietea bellardii, Loseleurio-Vaccinietea, Salicetea herbaceae
\end{abstract}

\section{P E 3 Ю M E}

Сообщества с Аоминированием Dryas octopetala в европейском секторе Арктики и Субарктики и на севере Западной Сибири принадлежат к 18 ассоциациям в 3 классах и 4 союзах. Синтаксономический спектр дриадовых тундр находится в соответствии с геоботаническим и флористическим Аелением Арктики и Субарктики. Союз Kobresio-Dryadion (кмасс Carici rupestris-Kobresietea bellardii) вкАючает сомкнутые и открытые ксеро-, мезофитные сообщества с преобладанием кустарничков и граминоидов, распространенные преимущественно в арктических и типичных тундрах европейской Арктики. Союз Dryado octopetalae-Caricion arctisibiricae в том же классе - Ариадовые сообщества со значительным участием травянистых мезофитов, с основным ареалом на севере южных тундр и в типичных тундрах на севере Печорской равнины. Ариадовые тундры также описаны в рамках союзов Cassiopo-Salicion herbaceae (класс Salicetea herbaceae) и Loiseleurio-Diapension (класc Loseleurio-Vaccinietea). В последнем предложен подсоюз Salicenion nummulariae, вкАючающий сообщества малоснежных каменистых и песчаных местообитаний в южных и типичных тундрах на северо-востоке европейского сектора Арктики и на севере Западной Сибири. Приведена синоптическая таблица ассоциаций Ариадовых тундр.

К $\mathbf{ю ~ ч е ~ в ~ ы ~ е ~ с м ~ о ~ в ~ а : ~ D r y a s ~ o c t o p e t a l a , ~ C a r i c i ~ r u p e s t r i s - K o b r e s i e t e a ~ b e l l a r d i i , ~ S a l i c e t e a ~ b e r b a - ~}$ ceae, Loseleurio-Vaccinietea, Ариадовые тундры, метод Браун-Бланке, европейский сектор Арктики, северо-западная Сиб̆ирь.

No m e n c la t u r e : Cherepanov (1997) for vascular plants, Ignatov et al. (2006) for mosses, Konstantinova \& Bakalin (2009) for liverworts, Santesson et al. (2004) for lichens. New syntaxa were named according to the Code of phytosociological nomenclature (Weber et al. 2000). Authors of syntaxa are given in the first citation, in the characteristic and in the prodromus.

\section{INTRODUCTION}

Dwarf shrub heathlands and grasslands with abundant Dryas octopetala play an important role in the Arctic vegetation. They cover either extensive or rather small areas in various Arctic regions, considerably enriching the biodiversity of tundra. They include a number of rare and endangered species. The syntaxonomical position and relations of these plant communities become more complicated as the number of newly described syntaxa increases. Dryas octopetala-dominated plant communities were described in several classes, but they are assigned mainly to the circumpolar Arctic-oroarctic class Carici rupestris-Kobresietea bellardii Ohba 1974, which comprises dwarf shrub heath and grasslands in snow-free habitats with soil moisture regime ranging from dry to mesic, on calcium-rich, neutral or weakly acidic soils. 
The concept of this class was developed by Ohba (1974), who studied Japanese dwarf shrubs- and grass-heath communities and subdivided the class into several regional orders. The order Kobresio-Dryadetalia (Br.-Bl. 1948) Ohba 1974 occurs in Scandinavia, Greenland, Svalbard, Arctic Canada, Alaska and Arctic Siberia. The order includes several alliances, and until now only one alliance, Kobresio-Dryadion Nordh. 1943, has been reported from Arctic and northern alpine Europe. This alliance occurs in the Scandinavian mountains, and comprehensively studied (Nordhagen 1927, 1936, 1955, Rønning 1965, Dahl 1987, Hadač 1989).

The concept of the class Carici rupestris-Kobresietea bellardii with the order Kobresio-Dryadetalia as the syntaxa comprising achionophytic and xeric dwarf shrub heath and grasslands was re-considered with description of the alliance Dryadion integrifoliae Ohba ex Daniëls 1982 that included Dryas integrifolia-dominated plant communities on mesic and wet soils in Northwest Greenland (Lünterbusch \& Daniëls 2004). As the synecological characteristics (soil moisture regime) of the whole class and order became broader, this class is considered to include hygro-, meso- and xerophytic vegetation types on temporarily wet-moist, mesic and dry, non-acidic soils.

During the last two decades the Dryas octopetala-dominated vegetation of the Russian Arctic was thoroughly studied using the Braun-Blanquet approach. Plant communities of alliances Oxytropidion nigrescentis Ohba 1974 and Androsacio arctisibiricae-Aconogonion laxmannii Kucherov \& Daniëls 2005 were described in central Chukotka (Kucherov \& Daniëls 2005). Dryas-dominated plant communities of the Wrangel Island were related to alliances Oxytropidion nigrescentis, Caricion nardinae, Dryadion integrifoliae (Kholod 2007). In the north-west of Putorana Plateau and on the south-west of North-Siberian Lowland Dryas octopetala-dominated plant communities were described as the association Dryado octopetalae-Caricetum sabynensis Telyatnikov 2011 in the class Carici rupestris-Kobresietea, the associations Dryado octopetalaeEriophoretum vaginati Telyatnikov 2010 and Racomitrio lanuginosi-Dryadetum octopetalae Telyatnikov 2010 in the class Loiseleurio-Vaccinietea Eggler $1952 \mathrm{em}$. Schubert 1960, and the association Salici reticulatae-Caricetum parallelae Telyatnikov 2011 in the class Salicetea herbaceae Br.-Bl. in Br.-Bl. et Jenny 1926 (Telyatnikov 2010 a, b, 2011). Plant communities with high cover of Dryas octopetala ssp. incisa in the southern Arctic tundra of Yamal Peninsula were described as the association Festuco ovinae-Dryadetum octopetalae Telyatnikov \& Pristyazhnyuk 2012 in the alliance Loiseleurio-Diapension (Br.-Bl. et al. 1939) Daniëls 1982 (Telyatnikov \& Pristyazhnyuk 2012). Dryas octopetala-dominated plant communities of Vaygach and Dolgyi Islands were investigated by Lavrinenko et al. (2014). Vegetation with a dominance of Dryas octopetala and Cassiope teragona on Svalbard and north of Fennoscandia was compared by Koroleva et al. (2008) and Koroleva (2011).

A new alliance Dryado octopetalae-Caricion arctisibiricae (Koroleva \& Kulyugina 2010) ex Koroleva in Chytrý et al. 2015, with three associations: Pediculari oederi-Dryadetum octopetalae (Andreev 1932) Koroleva et Kulyugina 2015, Salici reticulatae-Dryadetum octopetalae Koroleva et Kulyugina 2015 and Dryado octopetalae-Caricetum arctisibiricae (Koroleva et
Kulyugina) Koroleva in Chytrý et al. 2015, has been described. This syntaxonomical system was based on a contribution of original releves and compiled data (Andreev 1932, Dedov 2006) from Murmansk Region (Rybachyi Peninsula, Pechenga area, Khibiny Mts.), of Nenets District and Komi Republic (Pechora Plain, Yugorskii Peninsula and of foothills of Pay-Khoy Mountains), Yamal-Nenets District (western slopes of Polar Ural), and from Malozemel'skaja and Bolshezemel'skaja tundra in the east of European southern tundra.

Patterns of tundra vegetation cover over a broad geographical range from Fennoscandia to the northwestern Taimyr was studied by Virtanen et al. (1999), with special accent on the topographic sequence of plant communities. However, no large-scale gradient was described for any Dryas octopetala-dominated community. The objective of this study was a comparison of the Dryas octopetala-dominated plant communities along the latitudinal and longitudinal gradients in the European sector of the Arctic and western Siberia, summarizing available data from Svalbard, Vaygach and Dolgyi Islands, Scandinavian Mountains, Kola Peninsula, north of Pechora Plain, Yugorskii Peninsula, Yamal Peninsula, the western and eastern foothills of the Polar Urals and the northwestern part of Plateau of Putorana.

\section{MATERIALS AND METHODS}

Original data were collected during the fieldwork in Svalbard and the Kola Peninsula). Additional mateials were obtained from the earlier published literary sources containing syntaxonomical data, most of which were taken in accordance with the standard procedure of Braun-Blanquet approach (Westhoff \& van der Maarel 1973) using the 7-grade Braun-Blanquet cover-abundance scale. In this study, for unification the data from the literary sources we combined the Braun-Blanquet's grades $2 \mathrm{a}$ and $2 \mathrm{~b}$, used by some authors, to the grade 2 . Moreover some materials collected with the use of other methodology (analyses of coenofloras (species compositions) of vegetation formations, Telyatnikov 2003) were also included in this study. The data used came from the study sites widely distriobuted in the Arctic zone of European part of Russia (Fig. 1) and from the published papers. The size of relevés used for description of Dryas-dominated vegetation varied from 1 to $100 \mathrm{~m}^{2}$. Below, some specific features of geography and sampling methodology in different study sites are listed.

1. Svalbard: Pyramiden and Barentsburg surroundings, Kongsfjorden, Bockfjorden, Liefdefjorden and Woodfjorden, $78^{\circ} 04^{\prime} \mathrm{N}, 14^{\circ} 13^{\prime} \mathrm{E}$, in elevation range from 2 to $130 \mathrm{~m}$ a.s.l., (Rønning 1965, Hadač 1989, Möller 2000, Koroleva et al. 2008). Sizes of relevés are 1 (Rønning 1965), 4, 5, 6 (Hadač 1989), 1, 4, 10 (Möller 2000) and $4 \mathrm{~m}^{2}$ (Koroleva et al. 2008).

2. Fennoscandia, Norwegian coast: Reinøya Island, Porsanger fjord, $69^{\circ} 53^{\prime} \mathrm{N}, 19^{\circ} 34^{\prime} \mathrm{E}$ (Nordhagen 1955). Size of relevés is $4 \mathrm{~m}^{2}$.

3. Fennoscandia, Scandinavian Mts.: Skaitiaksla, Tausa, Solvågtind, Mace, Mikafjell, Finskefjell, $66^{\circ} 48^{\prime} \mathrm{N}, 15^{\circ} 42^{\prime} \mathrm{E}$ and $66^{\circ} 50^{\prime} \mathrm{N}, 15^{\circ} 48^{\prime} \mathrm{E}$, in elevation range from 370 to $1050 \mathrm{~m}$ a.s.l. (Nordhagen 1955). Size of relevés $4 \mathrm{~m}^{2}$.

4. Fennoscandia, Rybachyi (Fisher) Peninsula, Malaja Volokovaja (Pummanki) Bay, 69 $34^{\prime} \mathrm{N}, 32^{\circ} 64^{\prime} \mathrm{E}$ and $69^{\circ} 55^{\prime} \mathrm{N}$, 


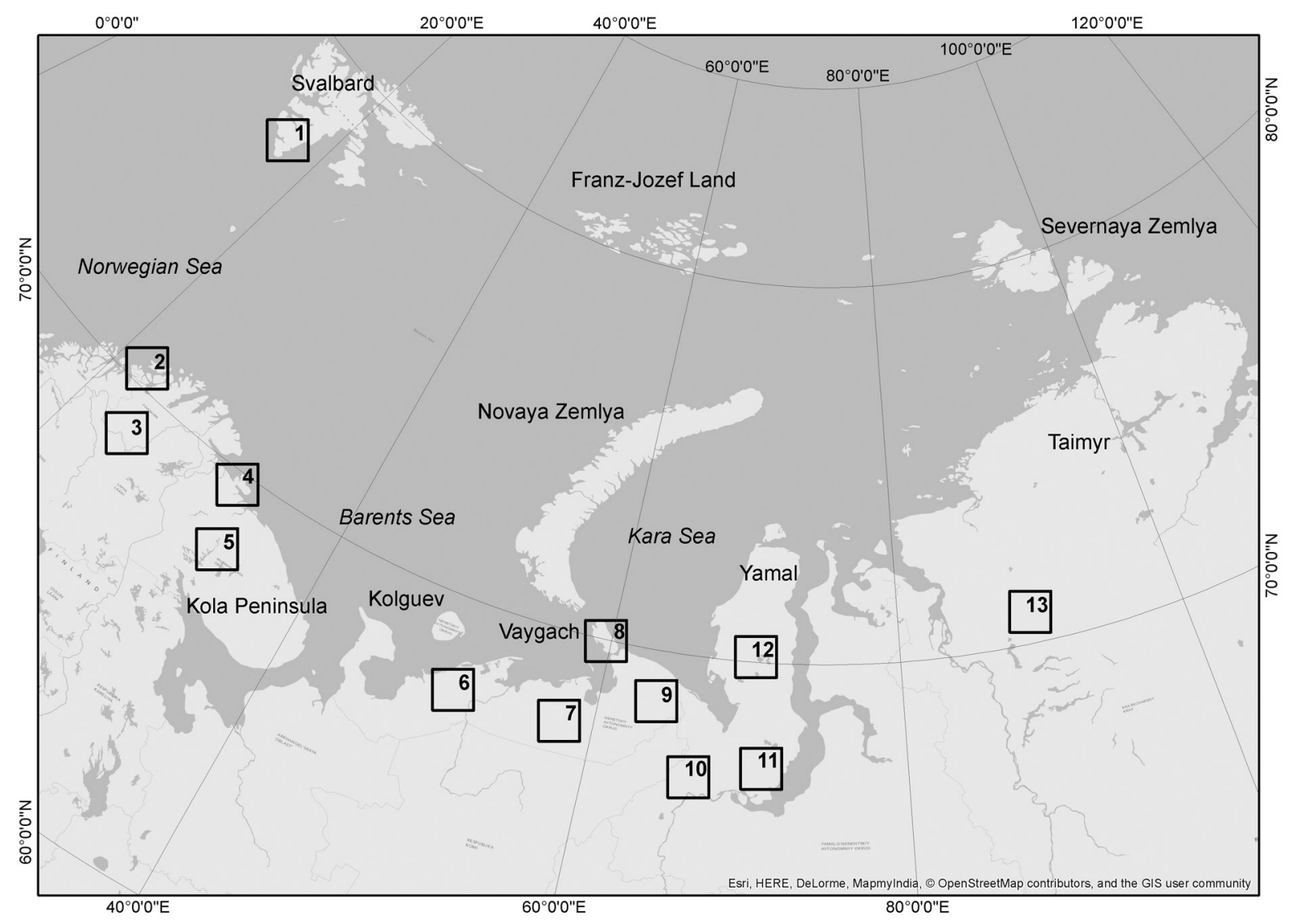

Figure 1 Locations of the study areas of Dryas octopetala-dominated plant communities. Numbers of areas as in the text and in the Table 1

$31^{\circ} 58^{\prime} \mathrm{E}$, in elevation range from 20 to $50 \mathrm{~m}$ a.s.l. (Kalliola 1939, Koroleva 2011). Size of relevés is $4 \mathrm{~m}^{2}$.

5. Fennoscandia, Kola Peninsula, Khibiny Mts., Pechengskie Tundry Mts., $67^{\circ} 34^{\prime}-67^{\circ} 53^{\prime} \mathrm{N}, 33^{\circ} 14^{\prime}-34^{\circ} 12^{\prime} \mathrm{E}$, in elevation range from 370 to $1100 \mathrm{~m}$ a.s.l. (Kalliola 1939, Koroleva 2011). Size of relevés is $4 \mathrm{~m}^{2}$.

6. Western part of Pechora Plain, Malozemel'skaja Tundra, $68^{\circ} 18^{\prime} \mathrm{N}, 53^{\circ} 14^{\prime} \mathrm{E}$ and $68^{\circ} 13^{\prime} \mathrm{N}, 50^{\circ} 51^{\prime} \mathrm{E}$, in elevation range from 40 to $100 \mathrm{~m}$ a.s.l. (Dedov 2006, Koroleva \& Kulyugina 2015 , in press). Size of relevés is $25 \mathrm{~m}^{2}$.

7. Pechora Plain, western part of Bol'shezemel'skaja Tun-

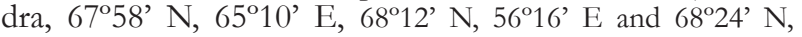
$56^{\circ} 10^{\prime}$ E (Andreev 1932, Koroleva \& Kulyugina 2015, in press). Size of relevés is $25 \mathrm{~m}^{2}$.

8. Vaygach and Dolgyi Islands, $70^{\circ} 01^{\prime} \mathrm{N}, 59^{\circ} 33^{\prime} \mathrm{E}$, in elevation range from 10 to $70 \mathrm{~m}$ a.s.l. (Lavrinenko et al. 2014). Size of relevés is $25 \mathrm{~m}^{2}$.

9. Yugorskii Peninsula, foothills of Pay-Khoy Mts., $69^{\circ} 03^{\prime} \mathrm{N}$, $62^{\circ} 08^{\prime} \mathrm{E}$ and $69^{\circ} 01^{\prime} \mathrm{N}, 62^{\circ} 11^{\prime} \mathrm{E}$, at elevation about $200 \mathrm{~m}$ a.s.l. (Lavrinenko et al. 2014, Koroleva \& Kulyugina 2015, in press). Size of relevés is $25 \mathrm{~m}^{2}$.

10. Western foothills of Polar Ural, $68^{\circ} 06^{\prime} \mathrm{N}, 65^{\circ} 48^{\prime} \mathrm{E}$, between 350 and $540 \mathrm{~m}$ a.s.l. (Koroleva \& Kulyugina 2015, in press). Size of relevés $25 \mathrm{~m}^{2}$.

11. Eastern foothills of Polar Ural, $67^{\circ} 28^{\prime} \mathrm{N}, 67^{\circ} 25^{\prime} \mathrm{E}$ and $67^{\circ} 41^{\prime} \mathrm{N}, 67^{\circ} 58^{\prime} \mathrm{E}$, at about $160 \mathrm{~m}$ a.s.l. (Telyatnikov \& Pristyazhnyuk 2012). Size of relevés is $100 \mathrm{~m}^{2}$.

12. Yamal Peninsula, $67^{\circ} 07^{\prime} \mathrm{N}, 68^{\circ} 12^{\prime}$ E, $69^{\circ} 42^{\prime} \mathrm{N}, 68^{\circ} 41^{\prime} \mathrm{E}$ and $70^{\circ} 24^{\prime} \mathrm{N}, 68^{\circ} 14^{\prime} \mathrm{E}$, at elevation $30 \mathrm{~m}$ a.s.l. (Telyatnikov 2003, Telyatnikov \& Pristyazhnyuk 2012). Size of relevés $100 \mathrm{~m}^{2}$.
13. North-western part of Putorana Plateau, $69^{\circ} 38^{\prime} \mathrm{N}, 90^{\circ} 34^{\prime} \mathrm{E}$, at elevation about $700 \mathrm{~m}$ a.s.l. (Telyatnikov 2009, 2010a, 2011). Size of relevés is $100 \mathrm{~m}^{2}$.

Among sites of Dryas octopetala-dominated communities there is a great variety of geographical conditions, namely in geology, relief, soils, climate and anthropogenic influence.

\section{Geology and geomorphology}

The geology of sites on Svalbard is very variable. In the inner fjord area, where communities of Kobresio-Dryadion were studied, Devonian limestones and Cretaceous sediments prevail in area of Pyramiden settlement, and Barentsburg surroundings belong to Cretaceous and Lower Carboniferous formation, with intrusions of smaller areas of Lower Tertiary sandstones. Devonian cover rocks prevail in area of the Woodfjorden in northern Spitsbergen (Aga 1986). Communities of Kobresio-Dryadion were described mainly on wind-exposed calcareous habitats of coastal terrains and lower mountain slopes, on primitive stony and gravelly soils.

Fennoscandia (including Kola Peninsula) is underlain by ancient Archean basement composed of siliceous rocks of the Baltic shield. In contrast, the most of northern Norway and part of northern Sweden belong to the Caledonian mountain range of Scandes, very sharply defined and rugged mountains with highest summits reaching 1000-1800 $\mathrm{m}$ a.s.l. Here, more eutrophic cambro-silurian rocks, mostly metamorphized shists, prevail. There are also outcrops 
of granites, gneisses and gabbros on the coastal areas of Troms and Finnmark. The mountainous landforms were strongly modified by weathering and glaciation, and landforms of the coastal areas by wave abrasion and land uplift. Dryas octopetala-dominated communities occur on shallow stony and gravelly cryosolic soils along wind-exposed rock ledges in the oroarctic zone and on well-developed soils with humic horizons ([podbur] in Russian soil classification) on seashore terraces of Varanger and Rubachyi Peninsula (Pechnov 1977, Ramberg et al. 2008).

The nepheline intrusions occurring in the Khibiny Mts., at elevations 800-1000 m a.s.l., in the western Kola Peninsula, define some biogeochemical features of landscape, which led to the formation of coarse, acid and more or less distinctly podzolised soils. Soil profile is weakly stratified, and the thickness of the bleached soil horizon decreases northwards and upwards (Koroleva \& Pereverzev 2007). Landscapes here were shaped by most recent Pleistocene glaciation and physical and chemical erosion and now are represented by flat top surfaces and plateaus, well-developed lateral and terminal moraines. Substrates containing calcium and magnesium carbonates, where communities of the alliance Kobresio-Dryadion occurs, are mainly developed in Scandinavian Mountains and are very rare or absent in the lowlands of Fennoscandia.

The Pechora Plain is partitioned by the Pechora River into the western (Malozemel'skaja Tundra) and eastern (Bol'shezemel'skaja Tundra) areas. The rocky basement is covered by Paleozoic and Mesozoic sediments, and by Quaternary morainic and Sea deposits. The northern part of the Pechora Plain represents undulating lowland, with numerous chain-like groups of 50-70 m high morainal ridges and hills (Russian local term - 'мусюры' [musyury]), and many lakes. Dryas octopetala-dominated communities rarely occur on ridges and slightly sloping hilltops, on fine-grained and clayey-loamy illuvial Al-Fe-humic soils (Russian term - 'подбур' [podbu:r]) and tundra gleyish soils (Ignatenko 1979) affected by cryoturbation. This and the following areas are situated within the continuous permafrost zone (Zoricheva 1963, Morgunova 1976).

Vaygach and Dolgyi Islands are composed of Ordovician and Permian rock complexes represented by clay shale, clay and sandy limestones, covered by $20 \mathrm{~m}$ thick, mosaiclike quaternary deposits. Dryas octopetala-dominated communities are widely distributed here in wind-swept habitats on marine terrains and bedrock outcrops, on carbonated loamy-gravelly soils affected by cryoactivity, which maintains polygons, steps and stripes (Lavrinenko et al 2014).

The Pay-Khoy Mountains extend from northwest to southeast of the Yugorskii Peninsula, and are composed of schists and sedimentary rocks (sandstones, marls and limestones). Foothills of Pay-Khoy Mountains represent an elevated undulating plain covered with Quaternary marine and glacial deposits. Dryas octopetala-dominated communities occur here on slightly peaty gleyish soils strongly affected by cryoturbation and solifluction (Koroleva \& Kulyugina 2015 , in press).

The western slopes of Polar Ural neighboring the PayKhoy Mountains consist of ultrabasic, basic, acidic and carbonate rocks. Dryas octopetala-dominated communities were described on prominent parts of slopes, from 200 to $550 \mathrm{~m}$ a.s.l., on slightly peaty gleyeish soils strongly affected by cryoturbation. Dryas octopetala-dominated communities of the eastern slopes of Polar Ural were studied in the orohemiarctic (subalpine) belt, at about $60 \mathrm{~m}$ a.s.l.

Yamal Peninsula forms an extensive continuous plain, where Paleozoic basement formations are overlaid by interstadial glacial Jurassic, Cretaceous and Quaternary sands and clays. These deposits are covered by Kara till and sandy silt, which is regarded as aeolian loess. Holocene formations as peat accumulation, aeolian and fluvial deposits are widely distributed, and communities with high abundance of Dryas octopetala have been described on sandy and clayey soils on prominent hilltops and upper parts of slopes of hills, with a prominent micro-relief resulting from strong cryoactivity (Astakhov et al. 1996, Forman et al. 1999).

The Putorana Plateau is situated at the northwestern edge of the Central Siberian Plateau and composed of Siberian trapps. The plateau is dissected by lakes and river valleys and has steep northwestern slopes, where Dryas octopetala communities were studied in the oroarctic (alpine) belt (Telyatnikov \& Pristyazhnyuk 2012).

\section{Climatic conditions}

Dryas-dominated plant communities occur mainly in intrazonal habitats and are generally xeric and snow-free. These communities depend not only on prevailing regional climate, but mainly on microclimate of habitats. The data from meteorological stations (Table 1) present only some general information about climate along the large scale gradient, and no data available about the site microclimate.

Mild temperature and moisture regime of the western part of the area (west of Fennoscandia and Svalbard) is influenced by its proximity to the Gulf Stream, and continental features of climate become more pronounced to the east. The annual mean temperature decreases considerably from the west (northern Fennoscandia) to the east (northwest of Siberia), from the south (northern Fennoscandia and Pechora Plain) to the north (Svalbard and Vaygach) and from lowland (Rybachyi Peninsula, Porsanger Fjord) to mountains (Khibiny and Scandes). The precipitation, and, consequently, snow depth, decrease from northern Fennoscandia to Yamal, but in the mountains and on foothills of Polar Ural and Pay-Khoy precipitation is higher.

\section{Geographical subdivision}

The zonal nomenclature adopted in different northern countries differs remarkably. The scheme of zonal and regional subdivision of Arctic in the former USSR was outlined theoretically by Gorodkov (1935), Aleksandrova (1971), Chernov \& Matveyeva (1979), and is based on the composition of prevailing growth forms and synusiae, structure and composition of plant communities on zonal sites - 'plakors' in sense of Vysotsky (1927) and Lavrenko (1947). Two vegetation zones, polar desert and tundra, are recognized at high latitudes in the northern hemisphere beyond the northern limit of forests, and we consider the Arctic to include both of them. The tundra zone is subdi- 
Table 1. Mean annual temperature and precipitation on meteorological stations in areas of described Dryas octopetaladominated plant communities

\begin{tabular}{|c|c|c|c|c|c|c|c|}
\hline $\mathrm{N}$ & Name of study area & $\begin{array}{l}\text { Nearest } \\
\text { meteosta- } \\
\text { tion } *\end{array}$ & $\begin{array}{l}\text { Coordi- } \\
\text { nates }\end{array}$ & $\begin{array}{l}\text { Eleva- } \\
\text { tion, } \mathrm{m} \\
\text { a.s.l. }\end{array}$ & $\begin{array}{l}\text { Corresponding zone, accor- } \\
\text { ding to Gorodkov } 1935 \text { / } \\
\text { CAVM Team } 2003\end{array}$ & $\begin{array}{l}\text { Annual } \\
\text { mean } \\
t,{ }^{\circ} \mathrm{C}\end{array}$ & $\begin{array}{l}\text { Mean annu- } \\
\text { al precipita- } \\
\text { tion, } \mathrm{mm}\end{array}$ \\
\hline 1 & Svalbard & Barentsburg & $\begin{array}{l}78^{\circ} 04^{\prime}, \mathrm{N} \\
14^{\circ} 15^{\prime} \mathrm{E}\end{array}$ & 73 & Arctic tundra / subzone B, C & -6.1 & 525 \\
\hline 2 & $\begin{array}{l}\text { Fennoscandia, Reinøya, } \\
\text { Porsanger fjord }\end{array}$ & Brennelv & $\begin{array}{l}70^{\circ} 04^{\prime} \mathrm{N}, \\
24^{\circ} 58^{\prime} \mathrm{E}\end{array}$ & 7 & Southern tundra, oroarctic belt & 0.9 & 450 \\
\hline 3 & $\begin{array}{l}\text { Fennoscandia, Scandinavian } \\
\text { Mts }\end{array}$ & Saltfjellet & $\begin{array}{l}66^{\circ} 33^{\prime} \mathrm{N} \\
15^{\circ} 19^{\prime} \mathrm{E}\end{array}$ & 676 & Oroarctic belt & -1.6 & 670 \\
\hline 4 & $\begin{array}{l}\text { Fennoscandia, Rybachyi } \\
\text { Peninsula }\end{array}$ & Vaida-Guba & $\begin{array}{l}69^{\circ} 56^{\prime} \mathrm{N} \\
31^{\circ} 59^{\prime} \mathrm{E}\end{array}$ & 8 & Southern tundra / subzone E & 1.7 & 506 \\
\hline 5 & Fennoscandia, Khibiny Mts. & Yukspor & $\begin{array}{l}68^{\circ} 10^{\prime} \mathrm{N} \\
32^{\circ} 23^{\prime} \mathrm{E}\end{array}$ & 794 & Oroarctic belt & -4 & 1340 \\
\hline 6 & $\begin{array}{l}\text { Pechora Plain, } \\
\text { Malozemel'skaja Tundra }\end{array}$ & Indiga & $\begin{array}{l}67^{\circ} 41^{\prime} \mathrm{N} \\
48^{\circ} 41^{\prime} \mathrm{E}\end{array}$ & 3 & $\begin{array}{l}\text { Southern and Typical tundra / } \\
\text { subzone E }\end{array}$ & $-2,4$ & 415 \\
\hline 7 & $\begin{array}{l}\text { Pechora Plain, } \\
\text { Bol'shezemel'skaja Tundra }\end{array}$ & Vorkuta & $\begin{array}{l}67^{\circ} 29^{\prime}, \mathrm{N} \\
64^{\circ} 01^{\prime} \mathrm{E}\end{array}$ & 165 & $\begin{array}{l}\text { Southern and Typical tundra / } \\
\text { subzone E }\end{array}$ & -3.0 & 323 \\
\hline 8 & Vaygach and Dolgyi Islands & $\begin{array}{l}\text { im. E.K. } \\
\text { Fedorova }\end{array}$ & $\begin{array}{l}77^{\circ} 43^{\prime} \mathrm{N} \\
104^{\circ} 18^{\prime} \mathrm{E}\end{array}$ & 12 & $\begin{array}{l}\text { Typical (Arctic) tundra / subzone } \\
\text { C, D }\end{array}$ & -6.5 & 240 \\
\hline 9 & $\begin{array}{l}\text { Jugorskii Peninsula (incl. } \\
\text { Pay-Khoy Mts.) }\end{array}$ & Amderma & $\begin{array}{l}69^{\circ} 45^{\prime} \mathrm{N} \\
61^{\circ} 42^{\prime} \mathrm{E}\end{array}$ & 53 & $\begin{array}{l}\text { Typical tundra, Oroarctic belt / } \\
\text { subzone E, D }\end{array}$ & -7 & 420 \\
\hline$\frac{10}{11}$ & $\begin{array}{l}\text { west of Polar Ural } \\
\text { east of Polar Ural }\end{array}$ & \begin{tabular}{|l|} 
no name \\
no name
\end{tabular} & \begin{tabular}{|l|}
-- \\
--
\end{tabular} & $\begin{array}{ll}-- \\
--\end{array}$ & $\begin{array}{l}\text { Oroarctic belt / subzone E } \\
\text { Oroarctic belt / subzone E }\end{array}$ & $-6--9$ & \begin{tabular}{|l|}
$1000-1500$ \\
$600-800$
\end{tabular} \\
\hline 12 & Yamal Peninsula & Marre-Sale & $\begin{array}{l}69^{\circ} 43^{\prime} \mathrm{N} \\
66^{\circ} 48^{\prime} \mathrm{E}\end{array}$ & 24 & $\begin{array}{l}\text { Southern and Typical tundra / } \\
\text { subzone E, D }\end{array}$ & -9.2 & 286 \\
\hline 13 & Putorana Plateau & Agata & $\begin{array}{l}69^{\circ} 53^{\prime} \mathrm{N} \\
93^{\circ} 28^{\prime} \mathrm{E}\end{array}$ & 277 & Oroarctic belt / subzone E, D & -11.4 & 410 \\
\hline
\end{tabular}

* Data from nearest to the sampled areas meteostation were taken: for Norwegian territory - from the database of the Norwegian Meteorological Institute http:/ / eklima.met.no; for Vaygach and Dolgyi Islands, Yamal Peninsula, eastern slopes of Polar Ural and Putorana Plateau - from publications (Telyatnikov 2011, Telyatnikov \& Pristyazhnyuk 2012, Lavrinenko et al. 2014); for Kola Peninsula, Pechora Plain, Yugorsky Peninsula - from the database HydroMeteorological DataBase (HMDB) of Institute of Biology Komi Science Center RAS, http://ib.komisk.ru/climat/index.php

vided into three major subzones: southern tundra, typical (or northern) tundra and arctic tundra. The names and delimitation of mountain zones (belts) follows to Ahti et al. (1968).

Study areas in Svalbard lie in the arctic tundra. North of Fennoscandia (the coastal lowlands of Finnmark, the Rybachyi Peninsula and a narrow (to $80 \mathrm{~km}$ wide) zone along the Barents Sea in Kola Peninsula have been regarded as southern tundra. Dryas-dominated communities studied on the Pechora Plain are situated in the north of southern tundra and in the typical tundra zone. Vaygach and Dolgyi Islands are considered by some authors to be situated within the arctic tundra (Aleksandrova 1977), while others (Lavrinenko et al. 2014) distinguish there the typical tundra and the oroarctic belt. Studies on Yamal peninsula were carried out in the southern and typical tundra, and descriptions of Dryas-dominated communities on the Pay-Khoy as well as in Polar Ural and Putorana were made in the orohemiarctic (subalpine) and in the oroarctic (alpine) zone or belt.

\section{Anthropogenic impact}

Areas of distribution of Dryas-dominated plant communities (especially Rybachyi Peninsula, north of Pechora Plain, Yamal Peninsula) are influenced by intensive reindeer husbandry. Consumption and trampling by reindeers essentially influence the structure and composition of plant communities on sandy and gravelly substrates, when fruticose lichen cover of Cladonia spp. reduces and cover of Stereocaulon spp. increases. The Dryas-dominated plant communities in coastal areas in Norway are grazed by sheep. The
Khibiny Mountains (Kola Peninsula) and the Polar Ural are strongly affected by mining.

\section{RES U LTS}

Dryas octopetala-dominated tundra communities of the European Arctic and in north-western Siberia were classified into 18 associations, which belong to 3 classes and 4 alliances (Table 2).

Prodromus of syntaxa of Dryas octopetala-dominated plant communities in European and West-Siberian Arctic

Class Carici rupestris-Kobresietea bellardii Ohba 1974

Order Thymo arctici-Kobresietalia bellardii Ohba 1974

Alliance Kobresio-Dryadion Nordh. 1943

Ass. Caricetum nardinae Nordh. 1935

Ass. Dryado-Caricetum rupestris (Rønning 1965) Hadač 1989

Ass. Dryado-Cassiopetum tetragonae (Fries 1913) Hadač (1946) 1989

Ass. Vulpicido tilesii-Dryadetum octopetalae Lavrinenko, Matveyeva et Lavrinenko 2014

Ass. Hedysaro arctici-Dryadetum octopetalae Lavrinenko, Matveyeva et Lavrinenko 2014

Subass. Hedysaro arctici-Dryadetum octopetalae typicum Lavrinenko, Matveyeva et Lavrinenko 2014

Subass Hedysaro arctici-Dryadetum octopetalae bistortetosum majoris Lavrinenko, Matveyeva et Lavrinenko 2014 
Ass. Saxifrago aizoidis-Dryadetum octopetalae Lavrinenko, Matveyeva et Lavrinenko 2014

Ass. Arenario pseudofrigidae-Dryadetum octopetalae Lavrinenko, Matveyeva et Lavrinenko 2014

Ass. Salici arcticae-Dryadetum octopetalae Lavrinenko, Matveyeva et Lavrinenko 2014

Ass. Campanulo unifloro-Elymetum (Nordh. 1928) Dierssen 1992

Ass. Dryadetum octopetalae (Nordh. 1928) 1955

Alliance Dryado octopetalae-Caricion arctisibiricae (Koroleva et Kulugina 2010) ex Koroleva in Chytrý et al. 2015

Ass. Dryado octopetalae-Caricetum arctisibiricae Koroleva et Kulyugina 2015

Ass. Salici reticulatae-Dryadetum octopetalae Koroleva et Kulyugina 2015

Ass. Pediculari oederi-Dryadetum octopetalae (Andreev

1932) Koroleva et Kulyugina 2015

Alliance?

Ass. Dryado octopetalae-Caricetum sabynensis

Telyatnikov 2011

Class Salicetea herbaceae Br.-Bl., Emb. \& Mol. 1947

Order Salicetalia herbaceae Br.-Bl.ap. Br.-Bl. \& Jenny 1928

Alliance Cassiopo-Salicion herbaceae Nordh. 1936

Ass. Salici polaris-Dryadetum octopetalae (Rønning

1965) Koroleva 2011

Class Loseleurio-Vaccinietea Eggler 1952 em. Schubert 1960

Order Rhododendro-Vaccinietalia Br.-Bl. in Br.-Bl. et Jenny 1926

Alliance Loiseleurio-Diapension (Br.-Bl. et al. 1939)

Daniëls 1982

Ass. Racomitrio lanuginosi-Dryadetum octopetalae Telyatnikov 2010

Suballiance Salicenion nummulariae suball. nov. prov.

Ass. Stereocaulono paschalis-Dryadetum octopetalae Koroleva et Kulyugina 2015

Ass. Festuco ovinae-Dryadetum octopetalae Telyatnikov et Pristyazhnyuk 2012 stat. nov.

Subass. Festuco ovinae-Dryadetum octopetalae typicum Telyatnikov et Pristyazhnyuk 2012 stat. nov.

Subass. Festuco ovinae-Dryadetum octopetalae saussuretosum alpinae Telyatnikov et Pristyazhnyuk 2012 stat. nov.

\section{Characteristics of syntaxa}

Class Carici rupestris-Kobresietea bellardii Ohba 1974 Order Thymo arctici-Kobresietalia bellardii Ohba 1974

Class and order include dwarf shrub heath and grasslands mainly in snow-free habitats on from dry to mesic, calcium-rich, neutral or weakly acidic substrates. Diagnostic taxa (DT) over most of the area studied are Dryas octopetala, Cassiope tetragona, Silene acaulis, Salix reticulata, Thalictrum alpinum, Pedicularis oederi, Oxytropis sordida, Astragalus subpolaris, Hedysarum arcticum, Rhytidium rugosum.
Alliance Kobresio-Dryadion Nordh. 1943 (synonyms, hereafter syn., Elynion bellardii Nordh. 1936, Caricion nardinae Nordh. 1935, Kobresion myosuroidis Nordh. 1943).

This alliance comprises achionophytic and xerophytic dwarf shrub heath and grasslands on weakly acidic, neutral or calcium-rich soils. The alliance is distributed in European arctic tundra (oroarctic belt) (Dierssen 1992). DT in area studied are the same as of the order and class with an addition of Kobresia myosuroides, Carex rupestris, C. glacialis, C. fuliginosa (syn. C. misandra), C. hepburnii (syn. C. nardina), Pedicularis dasyantha. Mosses Ditrichum flexicaule, Distichium capillaceum, Hypnum bambergeri, Tortula ruralis are common on calcareous rocky and gravelly substrates slightly covered by peaty and humic layer. Saxifraga oppositifolia and Bistorta vivivpara, which were considered to be characteristic for both order and class (Lavrinenko et al. 2014), have broad distribution and ecological amplitude. Saxifraga oppositifolia is characteristic species of Arenarion norvegicae Nordh. 1935 (Dierssen 1992), and Bistorta vivivpara is one of the most active species in arctic plant communities (Koroleva et al. 2008). They can scarcely be regarded as characteristic species for the Kobresio-Dryadion.

Ass. Caricetum nardinae Nordh. 1935 (Rønning 1965, p. 19, this paper, tab. 2, vegetation type 1 and 12). Syn. Nardino-Dryadetum (Rønning 1965).

Plant cover is open and represented by scattered isolated tussocks of sedges and cushions of dwarf shrubs. DT are Dryas octopetala and Carex hepburnii. Salix polaris and Saxifraga oppositifolia are among most constant vascular species. The Caricetum nardinae in Scandinavian Mountains differs by constant presence of DT of the class: Salix reticulata, Thalictrum alpinum, Astragalus subpolaris. Mosses Oncophorus wablenbergii and Hypnum bambergeri are most frequent in communities on Svalbard, among lichens Ochrolechia frigida is of greater importance.

The association occurs on very exposed gravelly habitats, with little or no snow cover in winter, and has a rather limited distribution in Svalbard, it is very rare in mountains in Norway and northern Sweden (Hadač 1989, Nordhagen 1955).

Ass. Dryado-Caricetum rupestris (Rønning 1965) Hadač 1989 (Koroleva 2011, pp. 25-27; this paper, tab. 2, vegetation type 2). Syn. Rupestri-Dryadetum Rønning 1965.

DT are Dryas octopetala, Carex rupestris, C. fuliginosa. Among the most prominent and constant vascular species are Saxifraga oppositifolia, Silene acaulis, Poa alpina. Ditrichum flexicaule is constant among the mosses.

Communities of this association occur in exposed and wind-swept localities with thin snow cover, and are widely distributed in Svalbard but rather rare in Scandinavian mountains.

Ass. Dryado-Cassiopetum tetragonae (Fries 1913) Hadač (1946) 1989 (Rønning, 1965, pp. 28-31; this paper, tab. 2, vegetation type 4).

Plant communities are well differentiated by the dominance of Cassiope tetragona and Carex fuliginosa (DT), with constant species Dryas octopetala, Salix polaris and Oxyria digy$n a$, and numerous more or less meso-, hygrophytic mosses, 


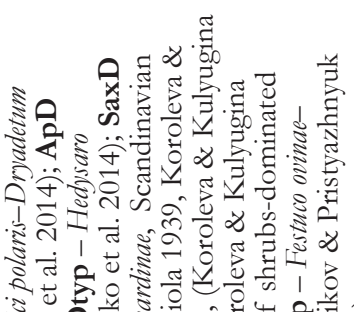

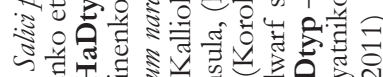

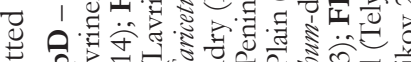

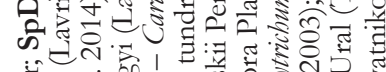

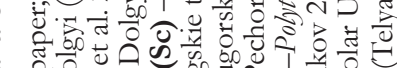

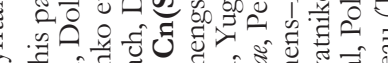
के

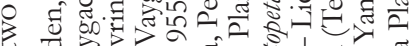
t

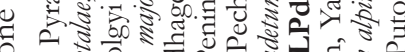

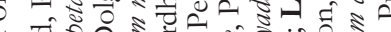
of

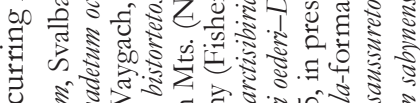
บั

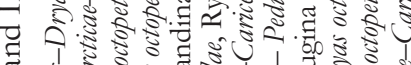

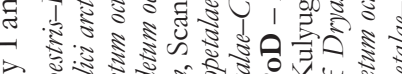

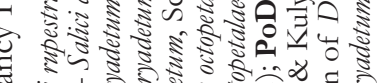

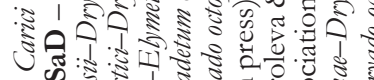
0

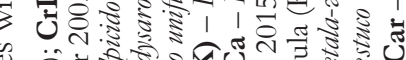

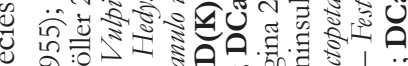

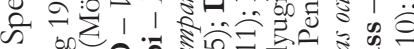

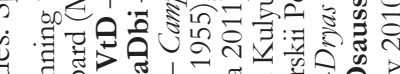

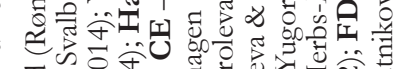

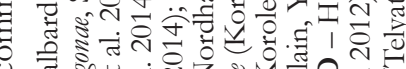

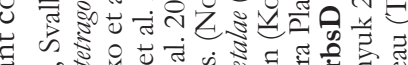

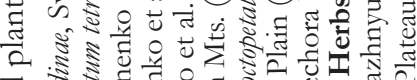
क ऑ

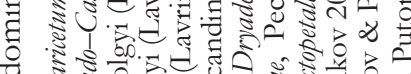

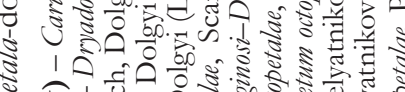

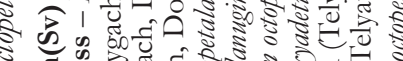

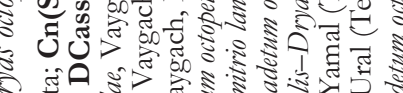

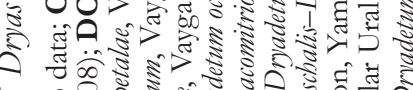

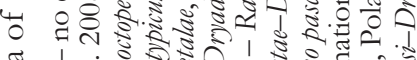

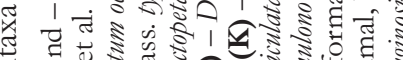

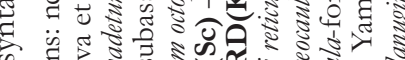
का पे 0 \%

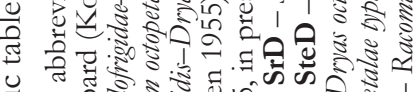

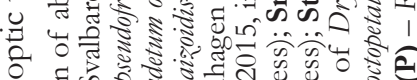

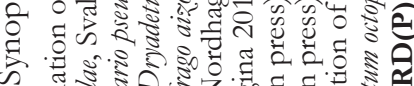

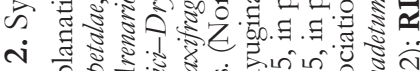
告

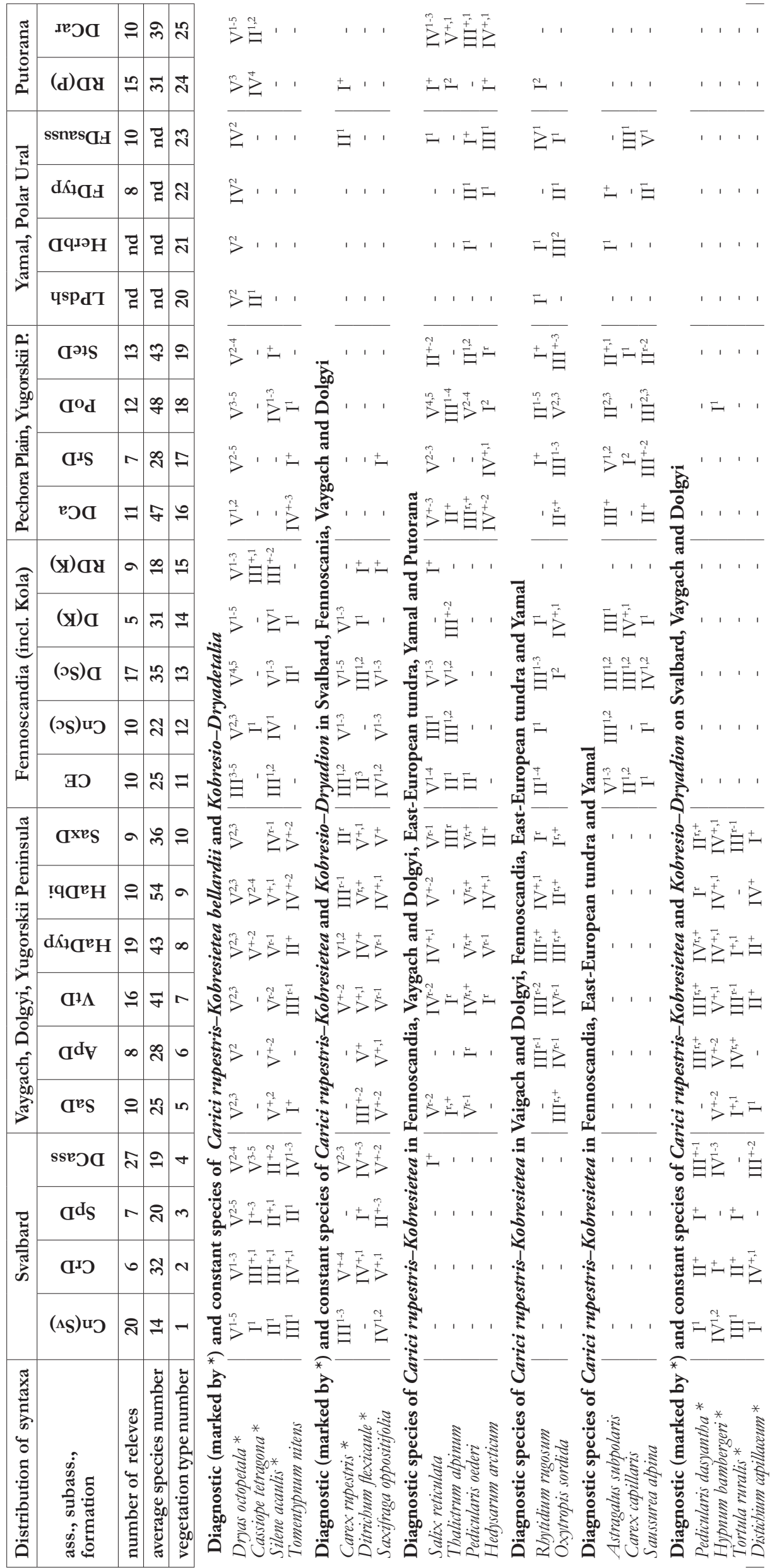




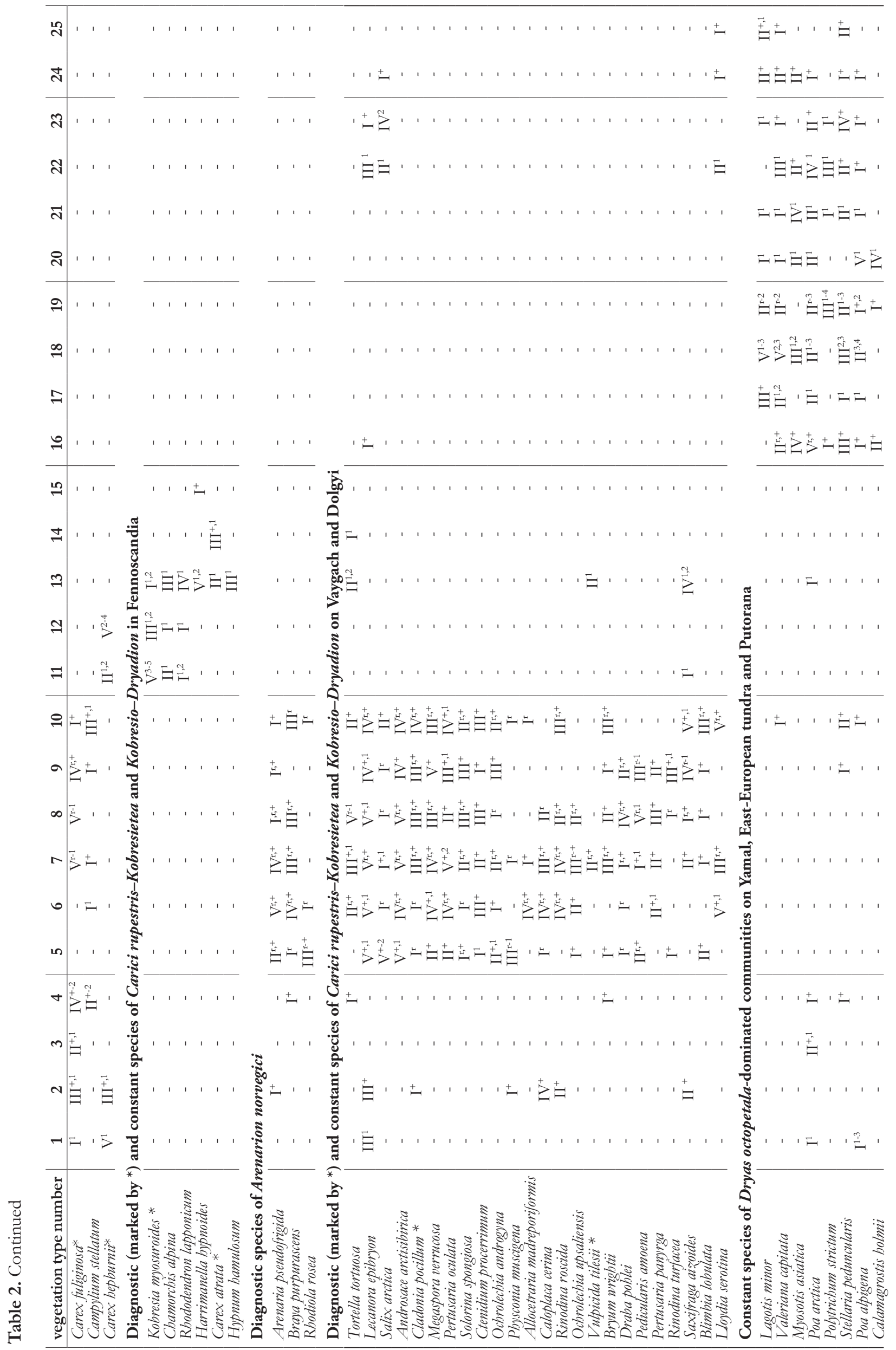




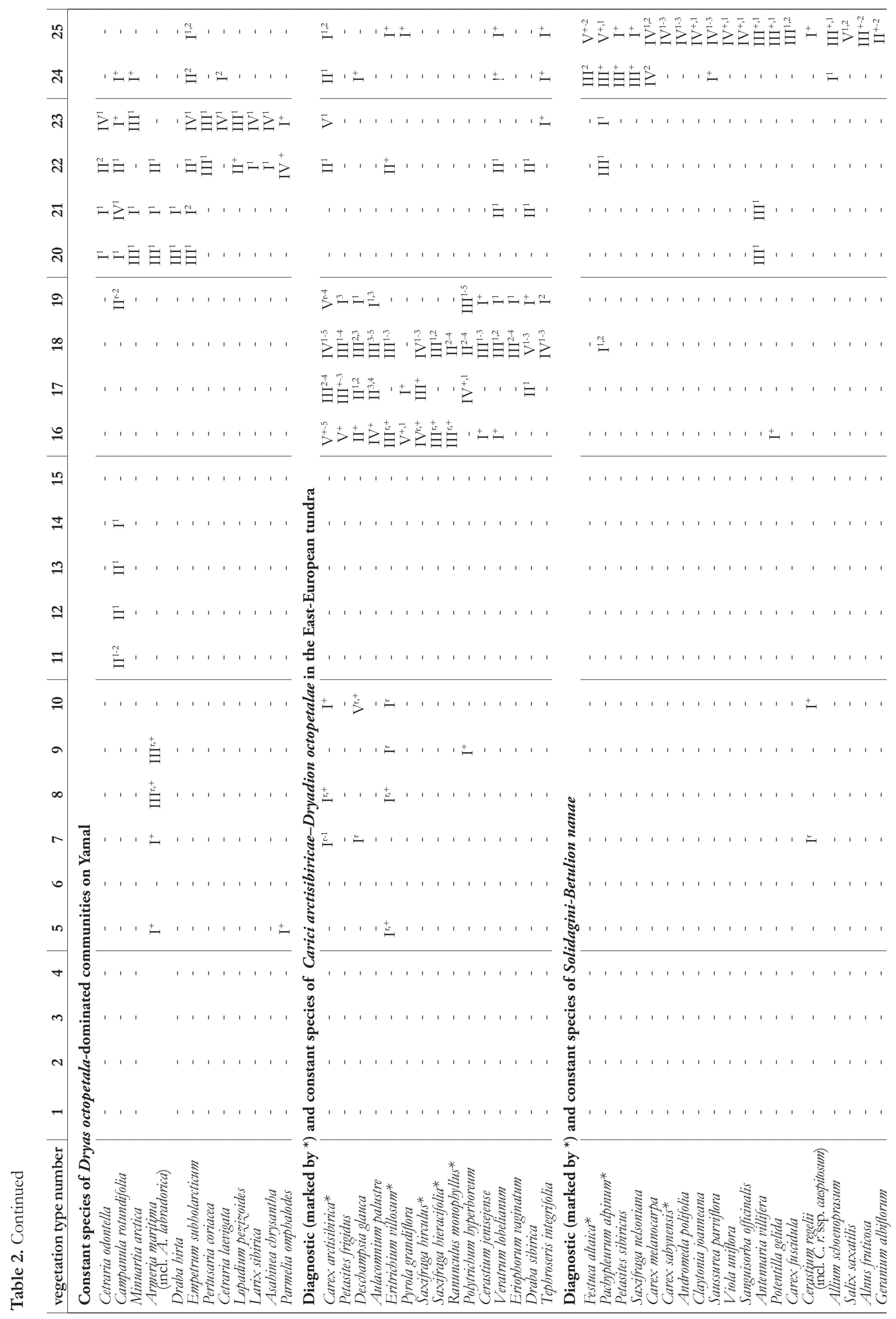




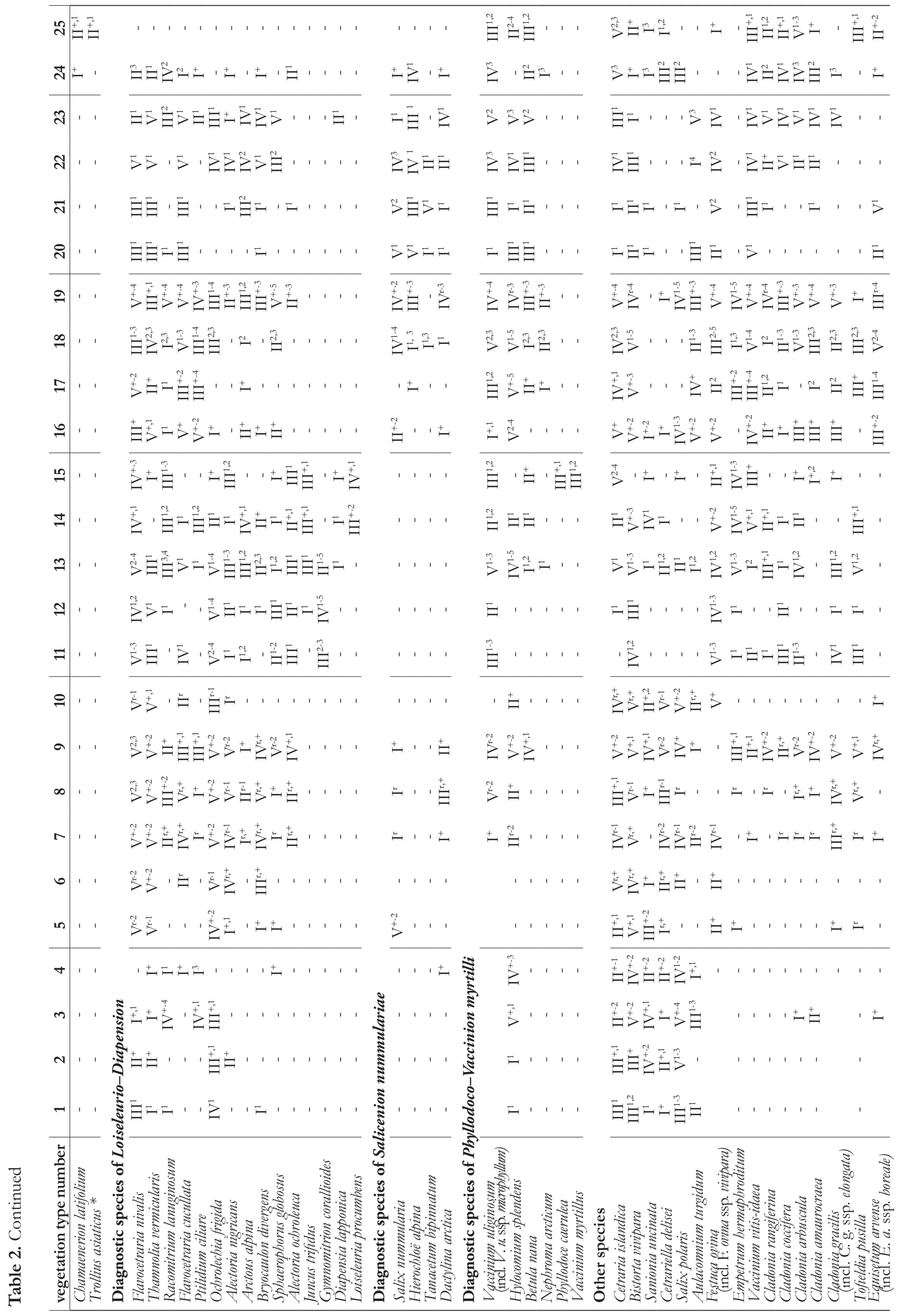




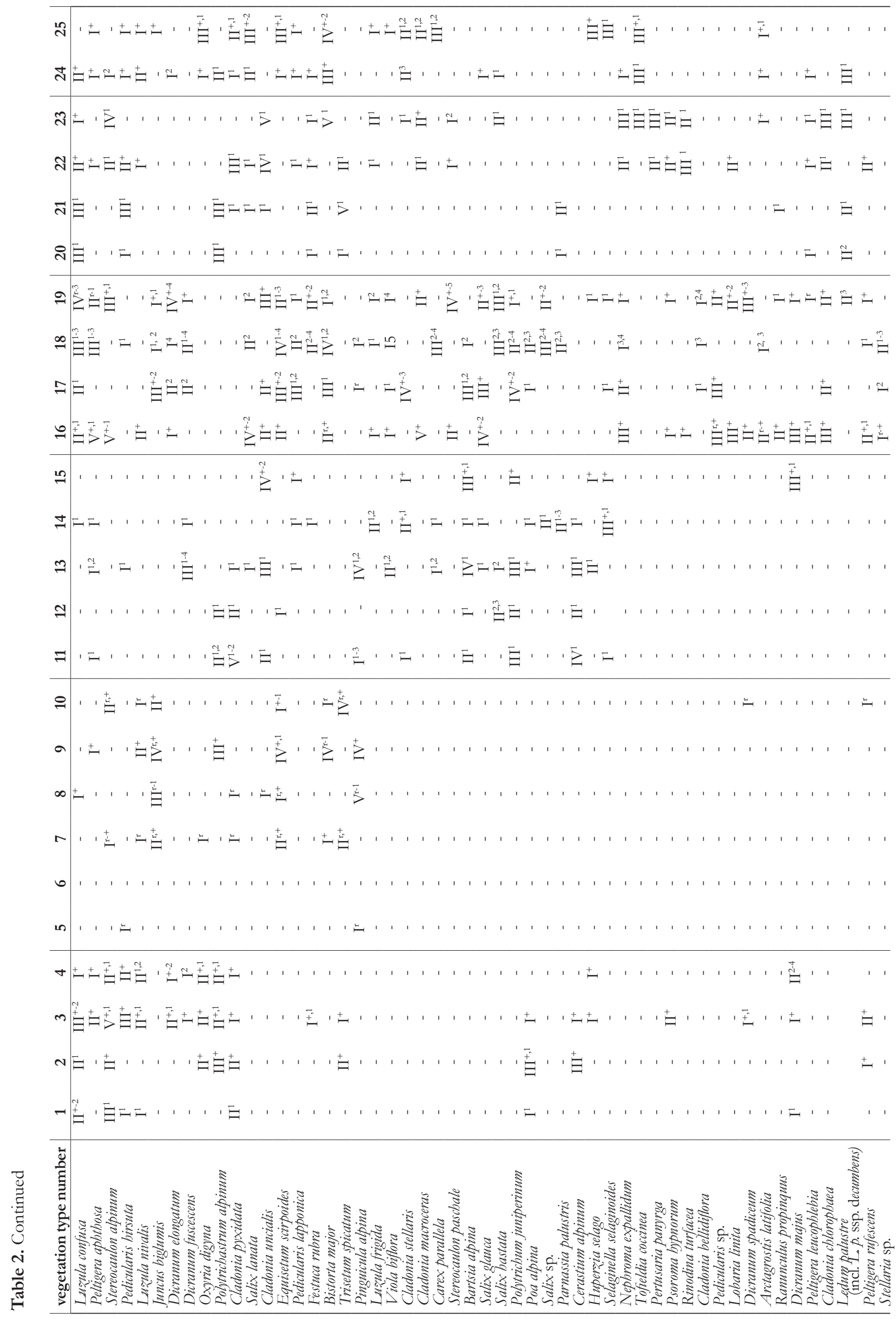




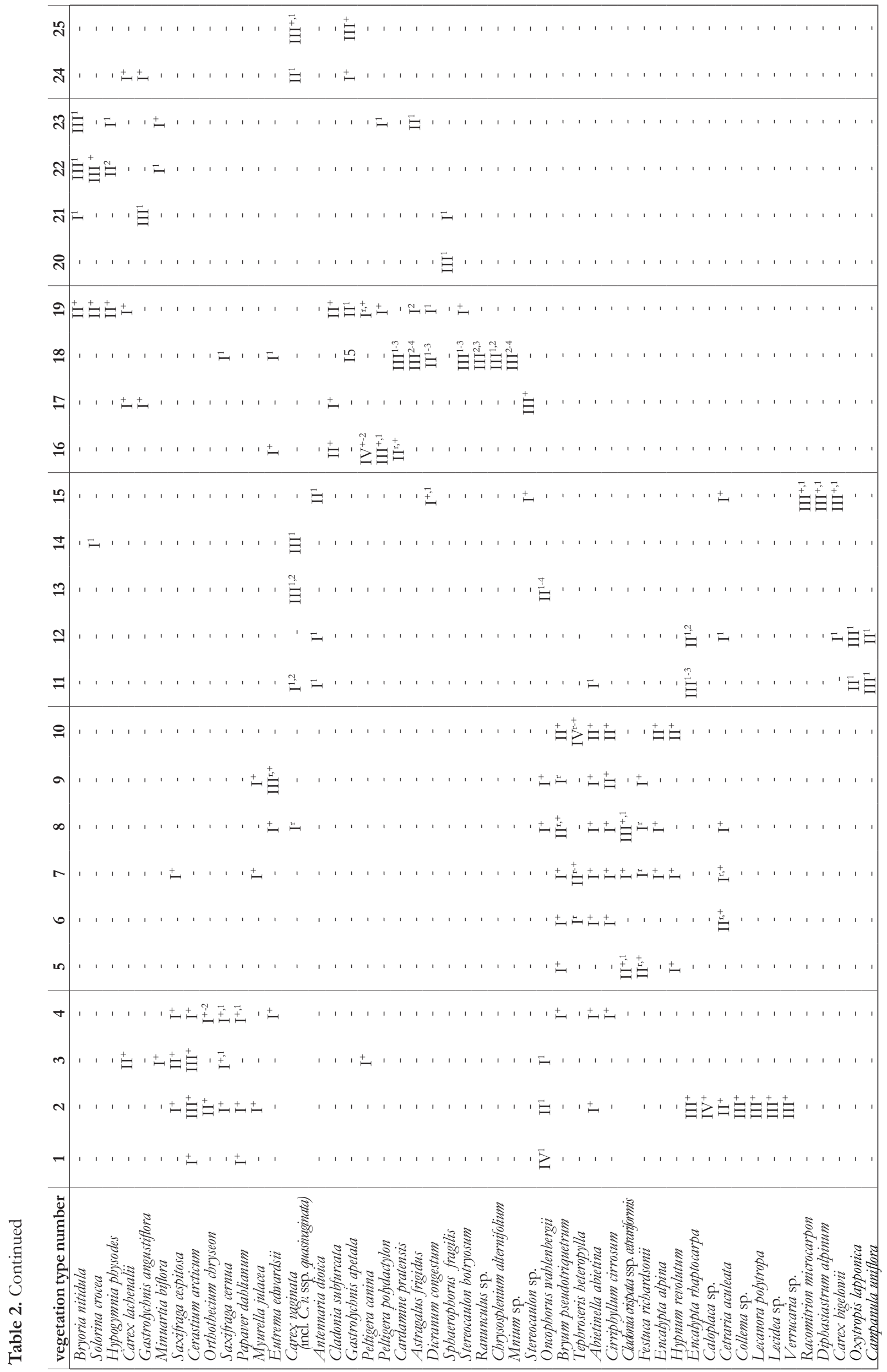


including Sanionia uncinata, Hylocomium splendens, Pleurozium schreberi and Tomentypnum nitens.

Plant communities occur in small wind sheltered depressions protected by snow in winter and with rather moist soil conditions in the growing season. They often form mosaic with the association Dryado-Caricetum rupestris on ridges. The association is common in most parts of Svalbard, with the exception of the northern- and easternmost regions, it is especially common on calcium-rich substrata on seashore terraces of inner fjords, and is rather rare in Scandinavian Mountains. Its zonal distribution is thought to be confined to the southern part of arctic tundra (southern and middle Arctic, dwarf shrub- and shrub zone of Daniëls et al. 2000).

Ass. Vulpicido tilesii-Dryadetum octopetalae Lavrinenko, Matveyeva et Lavrinenko 2014 (Lavrinenko et al. 2014, p. 45-50; this paper, tab. 2, vegetation type 7).

DT are Dryas octopetala, Carex rupestris, C. fuliginosa and Vulpicida tilesii. Among constant species are Androsace arctisibirica, Bistorta vivipara, Oxytropis sordida, Pedicularis oederi, Saxifraga oppositifolia, Silene acaulis, mosses Ditrichum flexicaule, Hypnum bambergeri, Rhytidium rugosum, and lichens Alectoria nigricans, Cetraria islandica subsp. crispiformis, Flavocetraria nivalis, Thamnolia vermicularis, Lecanora epibryon, Ochrolechia frigida, Pertusaria oculata.

Scattered mats of Dryas octopetala with other herbs, mosses and lichens form a downslope vegetation border around bare non-sorted gravelly half-circles. Communities of the association were described on south- and west-exposed slightly sloping seashore terraces on Vaygach Island and on the edges of steep river terrace on Yugorskii Peninsula.

Ass. Hedysaro arctici-Dryadetum octopetalae Lavrinenko, Matveyeva et Lavrinenko 2014 (Lavrinenko et al. 2014, p. 45-50; this paper, tab. 2, vegetation types 8 and 9).

Among DT and constants are Cassiope tetragona, Carex rupestris, C. fuliginosa, Vaccinium uliginosum, Armeria labradorica, Hedysarum arcticum, Juncus biglumis, Pinguicula alpina, Tofieldia pusilla, Dryas octopetala, Androsace arctisibirica, Bistorta vivipara, Pedicularis oederi, Saxifraga oppositifolia and Silene acaulis.

Open plant communities (average cover $60 \%$ ) occur mainly in more sheltered and snow-protected habitats in lower parts of south and west exposed slopes, on clayey and gravelly soils on maritime terraces, on the border of steep slopes along canyon-like river valleys on Vaygach Island. Two subassociations were distinguished, Hedysaro arctici-Dryadetum octopetalae typicum Lavrinenko, Matveyeva et Lavrinenko 2014 and Hedysaro arctici-Dryadetum octopetalae bistortetosum majoris Lavrinenko, Matveyeva et Lavrinenko 2014. The former subassociation includes open plant communities with dominance of Dryas octopetala and lichens, with constant presence of sedges and herbs, and communities of the latter subassociation are more closed, and with a greater abundance of Cassiope tetragona.

Ass. Saxifrago aizoidis-Dryadetum octopetalae Lavrinenko, Matveyeva et Lavrinenko 2014 (Lavrinenko et al. 2014, p. 51, 53; this paper, tab. 2, vegetation type 10).

DT are Deschampsia glauca, Saxifraga aizoides, Tephroseris heterophylla, Thalictrum alpinum, Trisetum spicatum and Campylium stellatum, dominants - Dryas octopetala, Salix polaris and To- mentypnum nitens. Vegetation mats form a network of strips surrounding polygons composed of clay with gravel on exposed wind-swept habitats on the flat and sloping maritime terraces of Vaygach Island.

Ass. Arenario pseudofrigidae-Dryadetum octopetalae Lavrinenko, Matveyeva et Lavrinenko 2014 (Lavrinenko et al. 2014, p. 41-42; this paper, tab. 2, vegetation type 6).

DT Arenaria pseudofrigida, Braya purpurascens, Tortula ruralis, Allocetraria madreporiformis, dominants Dryas octopetala and Silene acaulis, constant species - Flavocetraria nivalis, Thamnolia vermicularis, Lecanora epibryon and Hypnum bambergeri. Open plant communities, with an average $20 \%$ total cover, mosses and lichens are here intertwined into cushions of dwarf shrubs, crustose lichens grow on plants remains. Stands of the association occur on seashore terraces of Vaygach Island, on clayey and gravelly ground, with primitive peaty soils under fragments of the vegetation.

Ass. Salici arcticae-Dryadetum octopetalae Lavrinenko, Matveyeva et Lavrinenko 2014 (Lavrinenko et al. 2014, p. 43-44; this paper, tab. 2, vegetation type 5).

DT Salix arctica, S. nummularia, Rhodiola rosea and Physconia muscigena. Dominants are Dryas octopetala and Silene acaulis, constant species Androsace arctisibirica, Bistorta vivipara, Pedicularis oederi, Salix reticulata, Flavocetraria nivalis, Thamnolia vermicularis and Saxifraga oppositifolia. Plant cover is open, in average $40 \%$ of sample plot. Its horizontal structure is mosaic due to patterned ground, such as low-centered and flat polygons resulting from cryoturbation. Plant communities are located on the Dolgyi Island, on the marine terrain sloping towards the sea, on coarse gravelly soils, with numerous large stones at the surface.

In both associations, Salici arcticae-Dryadetum octopetalae and Arenario pseudofrigidae-Dryadetum octopetalae, the DT of the alliance Arenarion norvegici Nordh. 1935 Arenaria pseudofrigida, Braya purpurascens and Rhodiola rosea are constant and abundant. This alliance comprises base-rich to neutral scree and moraine communities of oroarctic and orohemiarctic belts of mountains of northern Europe (Valachovič et al. 1997). Both these associations show clear floristic and ecological similarities to the ass. Salici arcticae-Arenarietum pseudophrygidae Matveyeva, Lavrinenko et Lavrinenko 2013 (Matveyeva et al. 2013) of the Arenarion norvegici and are likely to occupy an intermediate position between this alliance and the Kobresio-Dryadion.

Ass. Campanulo unifloro-Elymetum (Nordh. 1928) Dierssen 1992 (Nordhagen 1955, p. 67 - 70; this paper, tab. 2, vegetation type 11). Syn. Kobresietum myosuroidis Nordh. (1928) 1955, Carici rupestris-Kobresietum myosuroidis (Nordh. 1935) Dahl 1987.

DT and dominants are Dryas octopetala and Kobresia myosuroides. Constant species are Saxifraga oppositifolia, Salix reticulata, Astragalus subpolaris, Festuca ovina, chionophobous lichens Flavocetraria nivalis, F. cucullata, Ochrolechia frigida.

The association was described from calcium-rich habitats in the upper oroarctic belt of Scandinavian Mountains, with two variants distinguished, the variant Kobresia myosuroides-Alectoria ochroleuca-Cetraria nivalis in dry snow-free habitats, with dominance of achionophytic lichens, and the 
variand Kobresia myosuroides-Rhytidium rugosum in moderately snow-protected habitats, with a prevalence of mosses Ditrichum flexicaule, Rhytidium rugosum, Abietinella abietina (Nordhagen 1955).

Ass. Dryadetum octopetalae (Nordh. 1928) 1955 (Nordhagen 1955, pp.77-81; this paper, tab. 2, vegetation types 1 and 14). Syn. Moosreiche Dryas octopetala-heide (Nordhagen 1927), artenreiche Dryas-soziation (Kalliola 1939).

DT are Dryas octopetala, Carex rupestris, Salix reticulata, Thalictrum alpinum. Dominant and constant species are Empetrum hermaphroditum, Arctous alpina, Silene acaulis, Vaccinium uliginosum. The association is characterized by large portion of hygro-, mesophytic herbs (Saussurea alpina, Saxifraga aizoides, Thalictrum alpinum, Tofieldia pusilla) and mosses (Hylocomium splendens, Racomitrium lanuginosum, Rhytidium rugosum) and together with the diagnostic species of the Loiseleurio-Diapension, such as the lichens Flavocetraria nivalis, Alectoria ochroleuca and Ochrolechia frigida.

The association is locally distributed in the lower and middle oroarctic belt in Scandinavian mountains, on the Norwegian and Barents Sea shore (on Varanger, Rybachyi (Fisher) Peninsulas) and islands (Reinøya, Magerøya, Sørøya) on calcium-rich rocky and sandy substrata, with moderate snow protection in winter.

The Dryado-Caricetum rupestris and Dryadetum octopetalae from Svalbard and from Scandinavia were united into one large and rather heterogeneous association Carici rupestrisDryadetum octopetalae (Nordh. 1928) Dierssen 1992 (Dierssen 1992). They are treated here as separate syntaxa basing on differences in species composition (Table 2), habitats and geographical distribution.

Alliance Dryado octopetalae-Caricion arctisibiricae (Koroleva et Kulugina 2010) ex Koroleva in Chytrý et al. 2015.

DT are Dryas octopetala (dominant), Carex arctisibirica (dominant), Salix reticulata, Pedicularis oederi, Astragalus subpolaris Thalictrum alpinum, Saxifraga hieracifolia, Saxifraga hirculus, Eritrichium villosum.

Differing from Kobresio-Dryadion, this alliance lacks the characteristic and constant species of Kobresio-Dryadion such as Carex rupestris, C. hepburnii, C. atrata, C. fuliginosa, and has a more mesophytic appearance due to co-dominance of Carex arctisibirica and Dryas octopetala and constant presence of herbs and grasses from DT of class and alliance.

Habitats of the alliance range from small to medium size, on well drained, warm and moderately snow protected hilltops and mainly south- and west-exposed slopes of hills ('musyury') on the north of Pechora Plain and on slopes of low foothills of Pay-Khoy mountains, on clayey, sandy and gravelly substrata, sometimes with frost boiling patches resulting from cryoturbation.

Plant communities of this alliance are rather rare in the western part of this area (in the Malozemel'skaja Tundra) but become more widely distributed to the east of Bol'shezemel'skaja tundra and Pay-Khoy Mountains, they represent the most species rich communities.

Ass. Dryado octopetalae-Caricetum arctisibiricae (Koroleva et Kulyugina) Koroleva in Chytrý et al. 2015 (Koroleva \& Kulyugina 2015, in print, Chytrý et al. 2015); this paper, tab. 2, vegetation type 16).
Dominants are Carex arctisibirica, Dryas octopetala, Salix polaris, S. reticulata, S. lanata (of plagiotropic growth form), moreover among diagnostic species are Pyrola grandiflora, Poa arctica, Luqula nivalis, Tomentypnum nitens, Stereocaulon alpinum, Peltigera aphthosa, P. canina. P. polydactylon, Cladonia macroceras. A high proportion of cover of mesophytic herbs (Bistorta vivipara, Hedysarum arcticum, Myosotis asiatica, Pyrola grandiflora) is indicative of a moderate water supply. Mosses (Aulacomnium turgidum, Hylocomium splendens, Tomentypnum nitens, Ptilidium ciliare etc.) form short and tough cover. Lichens are scattered, among them Cetraria islandica, Flavocetraria cucullata, Peltigera aphthosa, Stereocaulon alpinum, Thamnolia vermicularis are most common.

Plant communities of area 100-300 $\mathrm{m}^{2}$ occur on slightly sloping sites and the uppermost parts of morainic hills, in Yugorskii Peninsula and on foothills of Polar Ural, on cryogenic gleyish soils, depth of permafrost is $0.8 \mathrm{~m}$. These habitats are affected by severe overgrazing due to high density of passing reindeer herds.

Ass. Salici reticulatae-Dryadetum octopetalae Koroleva et Kulyugina 2015 (Koroleva \& Kulyugina 2015, in print; this paper, tab. 2, vegetation type 17).). Syn. Hylocomium proliferum-Carex byperborea (Dedov 2006).

DT are Dryas octopetala and Salix reticulata (dominants), mesophytic herbs, DT of alliance, Astragalus subpolaris and Hedysarum arcticum occur at high constancy. Hylocomium splendens and Aulacomnium turgidum prevail among mosses, Flavocetraria nivalis and Cladonia spp. among lichens. This association is differentiated from the Dryado octopetalae-Caricetum arctisibiricae by species composition, a higher portion of mosses (Polytrichum juniperinum, P. hyperboreum) and fruticose lichens (Cladonia stellaris) and closed cover of Dryas octopetala.

These plant communities occupy a few dozen of square meters on south-exposed tops of morainal hills, at about $200 \mathrm{~m}$ above sea level, on clayey and sandy soils, with permafrost at $0.5 \mathrm{~m}$ in depth. The association was rarely found in Malozemel'skaja and Bol'shezemel'skaja tundra, where the stands are affected by reindeer overgrazing.

Ass. Pediculari oederi-Dryadetum octopetalae (Andreev 1932) Koroleva et Kulyugina 2015 (Koroleva \& Kulyugina 2015, in print; this paper, tab. 2, vegetation type 18). Syn. association Dryas octopetala-Hylocomium proliferum and association Salix reticulata-Carex rigida-Hylocomium proliferumRhytidium rugosum ass. (Andreev 1932).

The dominants include dwarf shrubs Dryas octopetala, Salix reticulata, Vaccinium uliginosum and herbs Carex arctisibirica, Bistorta vivipara, Pedicularis oederi, Stellaria peduncularis, Lagotis minor. The vegetation has a grassland-like physiognomy and primarily contains meso-hygrophytic herbs and grasses, dwarf shrubs, pleurocarpous mosses and fruticose lichens. The vegetation stands are characterized by a small scale pattern of low tussocks of Carex arctisibirica and cushions of Dryas octopetala, and wet shallow hollows. Typical species on the small hummocks are Flavocetraria nivalis, F. cucullata, Thamnolia vermicularis, in the hollows, Hylocomium splendens occurs.

The association occurs rarely on steep south exposed slopes and hilltops of Bol'shezemel'skaja tundra, in the north of Pechorskaja lowland, on moderately to poorly drained clayey soils, with permafrost at $0.3-0.4 \mathrm{~m}$. 
Class Salicetea herbaceae Br.-Bl., Emb. \& Mol. 1947 Order Salicetalia herbaceae Br.-Bl.ap. Br.-Bl. \& Jenny 1928

Class and order comprise snow-bed vegetation with snow accumulation in winter and a shortened growing season; they are affected by snowmelt water and have an arcticalpine distribution. Among DT of the class and order in the study area are Salix herbacea, S. polaris, Harrimanella hypnoides, Cerastium regelii, Omalotheca supina, Beckwithia glacialis, Ranunculus nivalis, R. pygmaeus, R. sulphureus, Sagina cespitosa, Saxifraga rivularis, Sibbaldia procumbens, Taraxacum croceum, Viola alpina, Alopecurus alpinus, Luqula arctica, L. arcuata, L. confusa, Anthelia juratzkana, Cephalozia ambigua, Conostomum tetragonum, Gymnomitrium corallioides, G. apiculatum G. concinnatum, Kiaeria starkei, Moerckia blyttii, Pleurocladula albescens, Poblia drummondii, Polytrichum sexangulare, Racomitrium sudeticum, Sauteria alpina, Solorina crocea, Stereocaulon alpinum. Synusiae of bryophytes are of high importance, usually plant communities have well-developed closed moss (liverworts) layer and open scattered field layer of dwarf shrubs and graminoids.

\section{Alliance Cassiopo-Salicion herbaceae Nordh. 1936}

The alliance includes subnival communities on oligotrophic and mainly acid substrata in the circumpolar Arctic and in mountains of northern Europe. DT are Salix polaris, Ranunculus nivalis, R. sulphureus, Saxifraga rivularis, Cerastium regelii, Anthelia juratzkana, Blepharostoma trichophyllum, Gymnomitrium corallioides, G. apiculatum, G. concinnatum, Pleurocladula albescens, Poblia drummondii. They are distinguished by a dominance of herbs and graminoids (Luzula confusa), and prostrate dwarf shrubs (Salix polaris). The plant communities of this alliance in Svalbard are distinguished by a well developed layer of mosses and (or) liverworts, where they cover extensive areas on maritime terraces and in lower parts of mountain slopes.

Ass. Salici polaris-Dryadetum octopetalae (Rønning 1965) Koroleva 2011 (Koroleva 2011, pp. 24-26; this paper, tab. 2, vegetation type 3). Syn. Polari-Dryadetum (Rønning, 1965).

The absolute dominants are Salix polaris and Dryas octopetala, the moss layer is thick and rich in species, of which the most prominent are Sanionia uncinata, Hylocomium splendens, Racomitrium lanuginosum and Ptilidium ciliare. Among lichens Flavocetraria nivalis, Ochrolechia frigida, Stereocaulon alpinum are constant and abundant. Differing from associations of alliance Kobresio-Dryadion the constancy of DT of alliance is low (as for Cassiope tetragona, Silene acaulis, Tomentypnum nitens) or they are lacking (Carex rupestris, C. hepburnii).

Class Loseleurio-Vaccinietea Eggler 1952 em. Schubert 1960 (syn. Vaccinio-Piceetea Br.-Bl., ap. Br.-B1., Siss. et Vlg. 1939, Loiseleurio-Cetrarietea Suzuki-Tokio et Umezu in Suzuki-Tokio 1964, Vaccinio-Juniperetea communis Passarge in Passarge et G. Hofmann 1968, Betuletea rotundifoliae Mirkin et al. (1983) 1986).

Order Rhododendro-Vaccinietalia Br.-B1. in Br.-Bl. et Jenny 1926 (syn. Vaccinio-Piceetalia Br.-Bl., ap. Br.-Bl., Siss. et Vlg. 1939, Loiseleurio-Vaccinietalia Eggler 1952, Empetretalia hermaphroditi Schubert 1960, Deschampsio-Myrtilletalia Dahl 1957).

Class and order comprise dwarf shrub heathlands with a dominance of Empetrum hermaphroditum and other dwarf shrubs of the Ericacea, which play a major role in southern tundra (lower oroarctic and orohemiarctic belts in mountains of boreal and temperate zone). DT are Empetrum hermaphroditum, Arctous alpina, Vaccinium uliginosum, Betula nana, Phyllodoce caerulea, Diapensia lapponica, Loiseleuria procumbens.

Alliance Loiseleurio-Diapension (Br.-Bl. et al. 1939) Daniëls 1982 (syn. Loiseleurieto-Diapension Br.-Bl., ap. Br.-Bl., Siss. et Vlg. 1939, Loiseleurio-Arctostaphylion Kalliola 1939, Arctostaphylo-Cetrarion nivalis Dahl 1957, Empetro-Cetrarion nivalis Thannheiser 1975).

The alliance comprises achyonophytic and acidophytic dwarf shrub communities in southern tundra (oroarctic and orohemiarctic belts in mountains). The alliance was considered by F. Daniëls (1982) to occur in northern Scandinavia, Greenland, Iceland and probably in the western North America. DT are Diapensia lapponica, Loiseleuria procumbens, Arctous alpina, Juncus trifidus, Racomitrium lanuginosum, Ptilidium ciliare, Gymnomitrion corallioides. Among faithful taxa of this alliance are achionophytic lichens Flavocetraria nivalis, F. cucullata, Thamnolia vermicularis, Ochrolechia frigida, Alectoria nigricans, A. ochroleuca, Bryocaulon divergens, Sphaerophorus globosus.

Some of these lichen species are also present (and abundant) in communities of the Kobresio-Dryadion on basic and calcium-rich substrate because they are considered to depend on the microclimatic conditions of habitat rather than substrate characteristics. Their ecological amplitude is thus much wider than the amplitude of the Loiseleurio-Diapension (Daniëls 1982).

Ass. Racomitrio lanuginosi-Dryadetum octopetalae Telyatnikov 2010 (Telyatnikov 2010 a, p. 169-172; this paper, tab. 2, vegetation type 24). Syn. Racomitrio-Dryadetum octopetalae Koroleva 2011.

DT are Dryas octopetala, Cassiope tetragona, Racomitrium lanuginosum, Hierochloë alpina, Cetrariella delisei, Salix polaris. Among dominants are dwarf shrubs (Cassiope tetragona, Dryas octopetala, Vaccinium uliginosum, V. vitis-idaea, Salix polaris) and lichens (Cetraria islandica, Cladonia arbuscula, C. coccifera, C. rangiferina). Plant communities occur in snow-free wind exposed well-drained habitats in mountains of Kola Peninsula and in north-west of Plateau Putorana. Differing from communities of Kobresio-Dryadion, this association is lacking in diagnostic taxa of the alliance, except for Dryas octopetala and Cassiope tetragona.

Ass. Racomitrio-Dryadetum octopetalae Koroleva 2011 (Koroleva 2011, p. 29-30; this paper, tab. 2, vegetation type 15) was described in mountains of Kola Peninsula and attributed to the alliance Kobresio-Dryadion, but the name is illegitimate and has to be rejected as a later homonym. In accordance with the Principle of Priority of Code of phytosociological nomenclature (Weber et al. 2008) the correct name of a syntaxon is the earliest validly published, ass. Racomitrio lanuginosi-Dryadetum octopetalae Telyatnikov 2010.

Suballiance Salicenion nummulariae suball. nov. prov.

DT are Salix nummularia, Luqula confusa, Hierochloë alpina, Festuca ovina, Polytrichum hyperboreum, Racomitrium lanuginosum, Ptilidium ciliare, Thamnolia vermicularis, Flavocetraria nivalis, F. cucullata, Bryocaulon divergens, Alectoria nigricans, Sphaerophorus globosus, Dactylina arctica. 
Plant cover reaches $100 \%$, but mainly 70-80\%, with dominance and constant presence of hypoarctic, Arctic and alpine species: low and plagiotropic dwarf shrubs Salix nummularia (differential species of suballiance), Vaccinium uliginosum, V. vitis-iaea, Dryas octopetala and xero-, mesophytic grasses Luzula confusa, Hierochloë alpina, Festuca ovina, Carex arctisibirica, Trisetum spicatum, Poa arctica, P. alpigena and herbs Tanacetum bipinnatum, Antennaria villifera. There is a well-developed ground layer composed of mesophytic mosses (Hylocomium splendens, Dicranum majus), and achionophytic lichens (Flavocetraria nivalis, F. cucullata, Cetraria islandica, Bryocaulon divergens, Alectoria nigricans, Sphaerophorus globosus).

Achionophytic and oligotrafent plant communities of the suballiance occur on well drained, warm and from snow-free to moderately snow protected hilltops and gentle slopes of morainic hills and low mountains, on seashore terrains, on sandy and gravelly substrata, sometimes with frost boiling patches. The suballiance is distributed through the southern and typical tundra of the north-east of European Russia, and in the western part of northern Siberia. It is is closely related to syntaxa of dry open grasslands on sandy substrata described from the north of Pechora Plain (Kulyugina 2008) and Yamal (Ektova \& Ermokhina 2012).

Ass. Stereocaulono paschalis-Dryadetum octopetalae Koroleva et Kulyugina 2015 (Koroleva \& Kulyugina 2015, in print; this paper, tab. 2, vegetation type 19). Syn. Salix herbacea-Stereocaulon paschale ass. of dwarf shrubs-and-lichensdominated tundra, Empetrum nigrum-Polytrichum hyperboreum, Salix polaris-Polytricha ass. of dwarf shrubs-and-mosses-dominated tundra (Andreev 1932).

DT include those of suballiance and also Betula nana, Empetrum hermaphroditum, Dicranum elongatum, Racomitrium lanuginosum, Stereocaulon paschale. The association includes Dryas octopetala-dominated heathlands with a high portion of dwarf shrubs (Salix polaris, S. nummularia) and low grasses (Carex arctisibirica, Festuca ovina, Poa arctica, Luzula confusa). Lichens (Cetraria islandica, Flavocetraria nivalis, F. cucullata) are constant and abundant, and a high cover of Ocbrolechia frigida, Sphaerophorus globosus and Stereocaulon paschale results from reindeer overgrazing.

Stands of the association occupy dry and snow-free ridges and upper slopes of sandy and gravelly folded moraines and hills at about $150-180 \mathrm{~m}$, with permafrost at $1.5 \mathrm{~m}$ or deeper. They are distributed in the north of Pechora plain and in the foothills of Pay-Khoy. In Polar Ural this association was described in the upper oroarctic belt, in snow-free south-east exposed slope, on clayey and gravelly substrata with cryogenic bare earth patches.

Association Lichens-Polytrichum-dwarf shrubs of the formation Dryas octopetala (Telyatnikov 2003, p. 35-41; this paper, tab. 2, vegetation type 20).

This and the following vegetation types were described and named according to the dominant life form and species. Among constant species are Dryas octopetala (dominant), Salix nummularia, Hierochloë alpina, Poa alpigena, Calamagrostis holmii. Cover of dwarf shrubs and grasses is $25 \%$ and $10 \%$, cover of mosses (Aulacomnium turgidum, Rhytidium rugosum, Hylocomium splendens var. alaskanum, Polytrichastrum alpinum) and lichens (Flavocetraria nivalis, F. cucullata, Thamnolia vermicu- laris, Sphaerophorus globosus, Dactylina arctica) is $40 \%$. Plant communities occupy dry and moderately snow-protected habitats on sandy soils, on flat and sloping terrains of typical (northern) tundra of Yamal Peninsula.

Association Herbs-Dryas octopetala of the formation Dryas octopetala (Telyatnikov 2003, p. 35-42; this paper, tab. 2, vegetation type 21 )

Dominants are Dryas octopetala and Salix nummularia; species with high constancy - Myosotis asiatica, Campanula rotundifolia, Tanacetum bipinnatum, Trisetum spicatum, Festuca ovina, Equisetum arvense. Mosses and lichens cover $30 \%$ of sample plot, with constant species Polytrichastrum alpinum, Pohlia nutans, Thamnolia vermicularis, Flavocetraria nivalis, Cetraria islandica.

The microtopography of habitats of the association is hummocky, with ribbon-like hummocks forming steps perpendicularly downslope. Plant communities occur on sandy soils in ridges and slopes of seashore terrains in the middle Arctic tundra of Yamal Peninsula.

Ass. Festuco ovinae-Dryadetum octopetalae Telyatnikov et Pristyazhnyuk 2012 stat. nov. (Telyatnikov \& Pristyazhnyuk 2012, pp. 57-62; this paper, tab. 2, vegetation types $22,23)$.

Dominants and constant species are Dryas octopetala, Arctous alpina, Festuca ovina, Hierochloë alpina, Cladonia coccifera, Pertusaria coriacea and Bryoria nitidula. Plant communities with well defined layers: dwarf shrubs and herbs cover $40 \%$ and $20-25 \%$ of sample plot respectively, mosses $-20 \%$, lichens $-35 \%$. Habitats of association occur on flat and slightly sloping ridges and slopes of watershed hills, on well drained sandy and gravelly soils. The association was subdivided into two subassociations: Festuco ovinae-Dryadetum octopetalae typicum Telyatnikov et Pristyazhnyuk 2012 and Festuco ovinae-Dryadetum octopetalae saussuretosum alpinae Telyatnikov et Pristyazhnyuk 2012.

\section{Alliance?}

Ass. Dryado octopetalae-Caricetum sabynensis (Telyatnikov 2011) stat. nov. (Telyatnikov 2011, p. 67-71; this paper, tab. 2, vegetation type 25).

DT are Pachypleurum alpinum, Andromeda polifolia subsp. pumila, Claytonia joanneana, Saussurea parviflora, Viola uniflora, Sanguisorba officinalis, Oxyria digyna, Antennaria villifera, Potentilla gelida, Tofieldia pusilla, Gastrolychnis apetala, Carex fuscidula, C. sabynensis, Selaginella selaginoides, Equisetum scirpoides. Constant and dominant species are dwarf shrubs Dryas octopetala, Vaccinium uliginosum, Salix saxatilis, Andromeda polifolia, Betula nana and herbs Thalictrum alpinum, Pedicularis oederi, Hedysarum arcticum and other diagnostic species of the association. Mosses (Hylocomium splendens) and chionophytic lichens (Cetraria islanica, Cladonia arbuscula) cover $10 \%$ and $15-20 \%$.

Plant communities occur on prominent slightly sloping surfaces of oroarctic (goltzovyi) belt of Putorana Plateau, and are seasonally irrigated with melting snow water. Habitats represent complex of vegetation mats, stones and cryogenic patches of bare earth, sometimes displaced along the slope due to solifluction. 
The association was originally described in the alliance Caricion nardinae (syn. of Kobresio-Dryadion), but is lacking most DT of this alliance, though DT of the class Carici rupestris-Kobresietea and the order Thymo arctici-Kobresietalia (such as Dryas octopetala, Salix reticulata, Thalictrum alpinum, Pedicularis oederi, Hedysarum arcticum) are present with high constancy and coverage (Telyatnikov 2011). Moreover, there are a number of taxa, mainly mesophytic herbs with Siberian distribution, such as Festuca altaica, Carex melanocarpa, C. sabynensis, Claytonia joanneana, Saussurea parviflora, Viola uniflora. Some of these (Pachypleurum alpinum, Festuca altaica, Carex sabynensis) were included in the diagnostic combination of the alliance Solidagini-Betulion nanae Telyatnikov 2009, class Loiseleurio-Vaccinietea (Telyatnikov 2009). There appears to be a need for a new alliance in the Carici rupestris-Kobresietea bellardii for Dryas octopetala-dominated plant communities with a high portion of mesophytic herbs with Siberian areal.

\section{DISCUSSION}

Dryas-dominated communities along the gradient from Svalbard to western Siberia belong to the different classes and alliances. There is a high portion of diagnostic species of other higher rank syntaxa in Dryas communities (Table 2). Lichens and mosses from diagnostic species of the alliance Loiseleurio-Diapension (Flavocetraria nivalis, F. cucullata, Thamnolia vermicularis, Racomitrium lanuginosum, Ptilidium ciliare, Ochrolechia frigida, Alectoria nigricans, Bryocaulon divergens, Sphaerophorus globosus) are constantly presented in Dryas tundra. Diagnostic species of Phyllodoco-Vaccinion myrtilli (Vaccinium uliginosum, Hylocomium splendens, Betula nana, Pleurozium schreberi, Nephroma arcticum) are common in continental subarctic Dryas tundra. This confirms an idea about syntaxonomical contunuum in the arctic vegetation.

Generally, Dryas-dominated plant communities are referred to as 'intra-zonal' - mainly dependent on bedrocks and microclimates rather than climate, which controls the vegetation zones. However, it appeared that different Dryas octopetala syntaxa tightly follow the latitudinal and longitudinal geo-botanical divisions of the Arctic (Aleksandrova 1977) reflecting general structure and composition of the zonal vegetation pattern.

The alliance Kobresio-Dryadion has a wide European arctic and oroarctic range. This explains similarities of syntaxa of the Kobresio-Dryadion in Svalbard, Vaygach and Dolgyi and oroarctic belt in Scandinavian Mts. confirmed by the group of species (Carex rupestris, C. hepburnii, C. fuliginosa, Pedicularis dasyantha). However, in Scandinavian Mts. the associations of this alliance are rare and considered to be relic (Nordhagen 1955).

Regional differentiation of Dryas-dominated tundra confirms the ecogeographical division of the Arctic and is linked with partition of the Arctic tundra; moreover the distinctive differences between communities in Fennoscandia, Pechora Plain and Yamal can be driven by a variety of bedrocks and dissimilar Quaternary geological history.

According to Aleksandrova (1977), Svalbard is referred as the particular geobotanical autonomous district of Arctic tundra, and Vaygach and Dolgyi Islands were considered together with Novaja Zemlja Archipelago as the particular geobotanical sub-province (Vaygachsko-Novo-Zemel'skya sub-province) of the Arctic tundra. Floristic specificity of Svalbard Island was confirmed by Yurtzev et al. (1978), who regarded it as specific floristic sub-province. Our comparison of plant communities of the Kobresio-Dryadion in Svalbard vs Vaygach and Dolgyi, outlined a group of species common in both areas (Carex rupestris, C. fuliginosa, Saxifraga oppositifolia, Pedicularis dasyantha etc., Table 2). All of them have wide Arctic, meta-Arctic and Arctic-alpine distribution. However, such species as Carex hepburnii were encountered only in Svalbard while Salix reticulata, Thalictrum alpinum, Pedicularis oederi and Hedysarum arcticum were characteristic of Vaygach and Dolgyi Islands. No syntaxa were common to both areas that confirms their distinctive botanical states.

The alliance Dryado octopetalae-Caricion arctisibiricae of the Pechora Plain and eastern hilltops of Polar Ural was differentiated by Eritrichium villosum, Pyrola grandiflora, Saxifraga birculus, S. hieracifolia, Ranunculus monophyllus, Deschampsia glauca etc. (Table 2) that confirms distinctiveness of the zonal European tundra: Kola Peninsula represents the Kolskaja sub-province and the north of Pechora Plain - the EastEuropean sub-province of the East-European-West-Siberian Province of sub-Arctic tundra. This differentiation is linked as well with the floristic division of Arctic by Yurtzev et al. (1978), where the north of Pechora Plain belongs to a specific Kaninsko-Pechorskaya floristic sub-province. PayKhoy Mts. and Polar Ural also represent a distinctive subprovince in the geobotanical division of the Arctic.

Mesophytic herbs with Eurasian and Asian distribution, such as Lagotis minor, Valeriana capitata, Myosotis asiatica, Stellaria peduncularis, Salix nummularia, Hierochloë alpina, Tanacetum bipinnatum etc. differentiate Dryas-dominated communities to the east of Fennoscandia, on Pechora Plain, in Polar Ural, Yamal and Putorana. Their similarity depends in part on strong reindeer grazing pressure.

Data on Siberian Dryas octopetala-dominated communities are sparse, and these communities need further study and classification. Dryas tundra on Putorana Plateau with large part of mesophytic herbs with Asiatic (mainly Siberian) distribution (Trollius asiaticus, Saxifraga nelsoniana, Petasites sibiricus, Festuca altaica, Carex melanocarpa, C. sabynensis) remains to be ascribed to a distinct alliance.

Dryas-dominated vegetation in European and WestSiberian tundra is one of the most diverse and species-rich in the Arctic. It mainly occupies restricted areas scattered over a more extensive range. The average number of species per association varies from 14 (Caricetum nardinae on Svalbard) to 54 (Hedysaro arctici-Dryadetum octopetalae on the Dolgyi Isl.). Dryas-dominated communities host several endangered species: Leucorchis albida, Arnica alpina and AlchemiIla alpina in Kola area (Konstantinova et al. 2003), Astragalus frigidus, Cortusa matthioli, Eritrichium villosum, Coeloglossum viride, Pinguicula alpina, Potentilla gelida subsp. boreo-asiatica, Rhodoila quadrifida, Taraxacum nivale, Tephroseris heterophylla, T. tundricola (Matveeva 2006). Species-rich Dryas-dominated communities with numerous mesophytic herbs (Hedysarum arcticum, Castilleja actica, Delphinium middendorffi, Armeria maritima, Valeriana capitata) were described by Morozova et 
al. (2006) in southern tundra on Yamal and treated as rare plant community for Siberia (Koropachinsky 1996). Dryasdominated communities are critically important parts of the Arctic biodiversity deserving the high level of legal protection. Conservation efforts should be directed to the decrease of the strong anthropogenic pressure and reindeer overgrazing in the habitats. Natural distribution, structure and functions of Dryas-dominated communities as well as the long-term survival of their characteristic species should be considered as a top priority of biodiversity conservation in the Arctic.

\section{CONCLUSIONS}

The phytosociological study of Dryas octopetala-dominated plant communities in the European-West-Siberian sector of the Arctic on the base of Braun-Blanquet classification confirms the general ecogeographic and floristic division of the Arctic in spite of the 'intra-zonal' character of this vegetation. The differentiation of the Carici rupestrisKobresietea bellardii from Svalbard to the West Siberia is revealed at the alliance level. Dry and dry-mesic heath, grasslands and barrens related to the alliance Kobresio-Dryadion distributed mainly on the mountains in western European Arctic occur in the area studied in the arctic and typical tundra (Svalbard archipelago, Islands Vaygach and Dolgyi) and in the oroarctic belt of Fennoscandia. In the eastern part of the European tundra, mainland communities are dominated by Dryas octopetala and numerous mesic grasses and herbs, which belong to the alliance Dryado octopetalaeCaricion arctisibiricae.

Dryas octopetala-dominated communities lacking associated diagnostic species of the class Carici rupestris-Kobresietea bellardii and the order Thymo arctici-Kobresietalia were related to other syntaxonomical units, such as the alliance CassiopoSalicion herbaceae (class Salicetea herbaceae) and the alliance Loiseleurio-Diapension (class Loseleurio-Vaccinietea). In the latter a new suballiance is proposed, Salicenion nummulariae, comprising achionophytic, mainly acidophytic and oligotrophic plant communities on sandy and gravelly substrates in the southern and typical tundra of the north-east of the European part of Russia, and in the western part of northern Siberia. Therefore, the range of the alliance Loiseleurio Diapension stretches from the southern tundra to Siberian typical (northern) tundra and proves to be greater than was originally thought.

The syntaxonomical position of Dryas octopetala-dominated communities of Yamal, Polar Ural and Putorana is yet to be firmly established and needs additional study.

Dryas-dominated vegetation in European and northwest-Siberian tundra supports high biodiversity, occupies naturally restricted areas and hosts a number of endangered species. These plant communities represent high value habitats and need protection and monitoring.

\section{ACKNOWLEDGEMENTS}

The present study was supported by the Russian Foundation for Basic Research (grant 14-04-98810). I thank Aleksandra Loshkareva for the help with figure arrangement. My deep gratitude to Dr. Irina Tatarenko and Hilary
Wallace for valuable remarks for the text improvement and linguistic corrections.

\section{LITERATURE CITED}

Aga, O.J. (ed.) 1986. The Geological History of Svalbard. Evolution of an arctic archipelago. Stavanger, $121 \mathrm{pp}$.

Ahti, T., L. Hämet-Ahti \& I. Jalas 1968. Vegetation zones and their sections in northernmost Europe. Annales Botanici Fennici 5:169-211.

Aleksandrova, V.D. 1971. On the principles of zonal subdivision of Arctic vegetation. Botanicheskii Zhurnal 56(1):121 (in Russian). [Александрова В.А. Принципы 3онального Аеления растительности Арктики. Бот. журн. 1971. Т. 56, № 1. С. 1-21].

Aleksandrova, V.D. 1977. Geobotanical subdivision of the Arctic and Antarctic. Nauka, Leningrad, 188 pp. (in Russian). [Александрова В.А. Геоботаническое районирование Арктики и Антарктики. А.: Наука, 1977. 188 с.].

Andreev, V.N. 1932. Types of tundra of the west of 'Bol'shaya Zemlja'. Trudy Botanicheskogo Museya 25:121-268. (in Russian). [Андреев B.Н. Типы тундр запада Большой Земли // Труды ботанического музея. Вып. 25. А., 1932. C. 121-268].

Astakhov, V.I., F.A. Kaplyanskaya \& V.D. Tarnogradsky 1996. Pleistocene permafrost of west Siberia as a deformable glacier bed. Permafrost and Periglacial Processes 7:165-191.

CAVM Team 2003. Circumpolar Arctic Vegetation Map. Scale 1:7,500,000. Conservation of Arctic Flora and Fauna (CAFF) Map No. 1. U.S. Fish and Wildlife Service, Anchorage, Alaska.

Cherepanov, S. K. 1995. Vascular plants of Russia and neighboring countries (in boundaries of former USSR). S.-Pb, 992 р. [Сосудистые растения России и сопредельных государств (в пределах бывшего СССР). С.-Пб̆. 992 с.].

Chernov, Y.I. \& N.V. Matveyeva 1979. Regularities of zonal distribution of communities in Taimyr. In: Arkticheskive tundry i polyarnye pustyni Taimyra, (V.D. Aleksandrova, N.V. Matveyeva, eds.), pp. 166-200, Nauka, Leningrad (in Russian). [Чернов Ю.И., Матвеева Н.В. Закономерности зонального распределения сообществ на Таймыре // Арктические тундры и полярные пустыни Таймыра / под ред. В.А. Александровой и Н.В. Матвеевой. $\Lambda$. : Наука, 1979. С. 166-200].

Chytrý, M., F.J.A. Daniëls, R. Di Pietro, N. Koroleva \& L. Mucina 2015. Nomenclature adjustments and new syntaxa of Arctic-alpine and oromediterranean vegetation. Hacquetia 14(1): 103-114.

Dahl, E. 1987. Alpine-subalpine plant communities of South Scandinavia. Phytocoenologia 15(4):455-484.

Daniëls, F.J.A. 1982. Vegetation of the Angmassalik District, Southeast Greenland, IV. Shrub, dwarf shrub and terricolous lichens. Meddelelser om Gronland, Bioscience 10:1-78.

Daniëls, F.J.A., H. Bültmann, C. Lünterbusch \& M. Wilhelm 2000. Vegetation zones and biodiversity of the NorthAmerican Arctic. Berichte der Reinhold-Tüxen-Gesellschaft 12:131-151.

Dedov, A.A. 2006. Plant cover of Malozemel'skaja and Timanskaya Tundra. Syktyvkar. 159 pp. (in Russian). [Аелов A.A. Растительность Малоземельской и Тиманской тунАр. Сыктывкар, 2006. 159 с.].

Dierssen, K. 1992. Zur Synsystematik nordeuropäeischen Vegetationstypen. 1. Alpine Vegetation und floristisch verwandte Vegetationseinheiten tieferen Lagen sowie der Arktis. Berichte der Reinhold-Tüxen-Gesellschaft 4:191-226.

Ektova S.N.\& K.A. Ermokhina 2012. Vegetation of sandy outcrops of northern subarctic tundra subzone in central 
Yamal. Izvestia Samarskogo nauchnogo centra Rossiiskoi akademii nank 14 (1(5)):1412-1415. (in Russian). [Эктова C.Н., Epмохина К.А. Растительность песчаных обнажений северных субарктических тундр центрального Ямаца / / Известия Самарского научного центра Российской академии наук. 2012. Т. 14, № 1(5). С. 1412-1415].

Forman, S., Ó Ingólfsson, V. Gataullin, W.F. Manley \& H. Lokrantz 1999. Late Quaternary stratigraphy of western Yamal Peninsula, Russia: New constraints on the configuration of the Eurasian ice sheet. Geology 27(9): 807-810.

Gorodkov, B.N. 1935. Vegetation of tundra zone of the USSR. Izdatel'stvo Akademii Nauk SSSR, Moscow, Leningrad, 142 pp. (in Russian). [Городков Б. Н. Растительность тунаровой зоны СССР. М., $\Lambda .:$ ИзА-во АН СССР, 1932. 142 c.].

Hadač, E. 1989. Notes on Plant Communities of Spitsbergen. Folia Geobotanica et Phytotaxonomica 24(2):131-169.

Ignatenko, I.V. 1979. Soils of East-European tundra and forest-tundra. Nauka, Moscow, 280 pp. (in Russian). [Игнатенко И.В. Почвы восточно-европейской тундры и месотундры. М.: Наука, 1979. 255 с.].

Ignatov, M.S., O.M. Afonina \& E.A. Ignatova 2006. Checklist of mosses of East Europe and North Asia. Arctoa: 15:1-130.

Kalliola, R. 1939. Pflanzensoziologische Untersuchungen in der alpinen Stufe Finnisch Lapplands. Annales Botanici Societatis Vanamo 14:1-321.

Kholod, S.S. 2007. Classification of the Wrangel Island vegetation. Rastitel'nost' Russii 11:3-135 (in Russian). [ХолоA C.C. Классификация растительности острова Врангеля. Растительность России. 2007. № 11. С. 3-135].

Konstantinova, N.A. \& V.A. Bakalin 2009. Check-list of liverworts (Marchantiophyta) of Russia. Arctoa 18:1-64.

Konstantinova, N.A., A.S. Koryakin \& O.A. Makarova (eds.) 2003. Red Data Book of Murmansk Region. Murmanskoe knizhnoe izdatel'stvo, Murmansk, 400 pp. (in Russian). [Kpacная книга Мурманской области / под реА. Н.А. Константиновой, А.С. Корякина и О.А. Макаровой. Мурманск: Мурманское книжн. изА-во, 2003. 400 с.].

Koroleva, N.E., N.A. Konstantinova, O.A. Belkina, A.Y. Likhachev, D.A. Davydov, A.N. Savchenko \& I.N. Urbanavichene 2008. Flora and vegetation of the Grenfjord area (Spitsbergen archipelago). K\&M, Apatity, 132 pp. (in Russian). [Королева Н.Е., Константинова Н.А., Белкина О.А., Аихачев А.Ю., Аавыдов А.А., Савченко А.Н., Урбанавичене И.Н. ФАора и растительность побережья залива Грен-фьорА (архипелаг Шпицберген). Апатиты: K\&M, 2008. C. 11-39].

Koroleva, N.E. 2011. On syntaxonomy of Dryas octopetala L. dominated tundra plant communities of Fennoscandia and Spitsbergen. Trudy Karelskogo Nauchnogo Tsentra RAN 1:23-36 (in Russian). [Королева Н.Е. К синтаксономии растительных сообществ с Аоминированием Dryas octopetala L. в Фенноскандии и на Шпицбергене / / Tруды КарНЦ РАН. 2011. № 1. С. 23-36].

Koroleva, N.E. \& E.E. Kulyugina 2015. To syntaxonomy of Dryas octopetala L. dominated plant communities in the Russian European Sub-Arctic. Trudy Karelskogo Nauchnogo Tsentra RAN, in print (in Russian). [Королева H.E., Кумюгина Е.Е. К синтаксономии Ариадовых тундр Европейского сектора Российской Субарктики // Труды КарНЦ РАН. В печати].

Koroleva, N.E. \& V.N. Pereverzev 2007 Zonal types of vegetation and soils in tubdras of Murmansk Province. Byulleten' Moskovskogo Obshchestva Ispytatelei Prirody 112(4):23-30 (in Russian). [Королева Н.Е., Переверзев
В.Н. Зональные типы растительности и почв в тунАрах Мурманской области // Бюмл. МОИП. ОтА. Биом. 2007. Т. 112, вып. 4. С. 23-30].

Koropachinsky I.Y. (ed.) 1996. Green Book of Siberia. Rare and endangered plant communities. Nauka, Novosibirsk, 398 pp. (in Russian). [Зеленая книга Сибири. Редкие и нуждающиеся охране растительные сообщества / поА реА. И.Ю. Коропачинского. Новосибирск: Наука, 1996.398 с.].

Kulyugina, E.E. 2008. Vegetation of sandy outcrops of Pechora tundra. Rastitel'nost' Rossii 12:39-61 (in Russian). [Кулюгина Е.Е Растительность песчаных обнажений Припечорских тунар // Растительность России. 2008. № 12. C. 39-61].

Kucherov, I. \& F.J.A. Daniëls 2005. Vegetation of the classes Carici-Kobresietea and Cleistogenetea squarrosae in Central Chukotka. Phytocoenologia 35(4):1019-1066.

Lavrenko, E.M. 1947. Principles and units of geobotanical division. In: Geobotanicheskoye rajonirovaniye SSSR (E.M. Lavrenko, ed.), pp. 9-13. Izdatel'stvo AN SSSR, Moscow, Leningrad, 1947 (in Russian). [Аавренко E.M. Принципы и единицы геоботанического районирования СССР // Геоботаническое районирование / поА. реА. Е.М. Аавренко. М.-А.: ИзА-во АН СССР, 1947. C. 9-13].

Lavrinenko, O.V., N.V. Matveyeva \& I.A. Lavrinenko 2014. Dryas communities in the East of the European part of the Russian Arctic. Rastitel'nost' Rossii 24:38-62. (in Russian). [Аавриненко О.В., Н.В. Матвеева, И.А. Аавриненко. Ариадовые сообщества на востоке европейской части Российской Арктики // Растительность России. 2014. № 24. C. 38-62].

Lünterbusch, C.H. \& F.J.A. Daniëls 2004. Phytosociological aspects of Dryas integrifolia vegetation on moist-wet soil in Northwest Greenland. Phytocoenologia 34(2):241-270.

Matveeva, N.V. (ed.) 2006. Red Data Book of Nenets Autonomous District. Nar'yan-Mar, 432 pp. (in Russian). [Красная книга Ненецкого автономного округа / отв. реА. Н.В. Матвеева. Нарьян-Мар, 2006. 432 с.].

Matveyeva, N.V., O.V. Lavrinenko \& I.A. Lavrinenko 2013. Plant communities with Arenaria pseudofrigida (Ostenf. et Dahl) Juz. ex Schischk.) on islands of south-eastern part of Barents Sea. Rastitel'nost' Rossii 22: 75-85 (in Russian). [Матвеева Н.В., Аавриненко О.В., Аавриненко И.А. Сообщества с Arenaria psendofrigida (Ostenf. et Dahl) Juz. ex Schischk.) на островах юго-восточной части Баренцева моря // Растительность России. 2013. № 22. C. 75-85].

Möller, I. 2000. Pflanzensociologische und vegetationsokologische Studien in Nordwestspitsbergen. Mittheilungen der Geographische Gesellschaft in Hamburg 90, 202 s.

Morgunova, N.A. (ed.) 1976. Atlas of Arkhangel'sk Region. 1976. Glavnoje upravlenije geodezii i kartografii pri Sovete ministrov, Moscow, 72 pp. (in Russian). [Атлас Архангельской области / ГАавное управле ᄀние геодезии и картографии при Совете министров СССР. М, 1976. $72 \mathrm{c.}$.

Morozova, L.M., M.A. Magomedova \& S.N. Ektova 2006. Structure of plant cover and phytocoenotic diversity. In: Yamal Peninsula: plant cover. Tyumen, pp. 148-205, 327-333 (in Russian). [Морозова А.M., Магомедова M.А., Эктова С.Н. Структура растительного покрова и фитоценотическое разнообразие // Полуостров Ямал: растительный покров. Тюмень, 2006. С. 148 205, 327-333].

Nordhagen, R. 1927. Die Vegetation und Flora des Sylenegebietes. I. Die Vegetation. Skrifter utgitt av det Norske videnskaps-akademi i Oslo. I. Matem.-naturvid. klasse. $611 \mathrm{s.}$ 
Nordhagen, R. 1936. Versuch einer neuen Einteilung der subalpinen-alpinen Vegetation Norwegegens. Bergens $\mathrm{Mu}$ seum Arbok, Naturvidensk. $88 \mathrm{~s}$

Nordhagen, R. 1955. Kobresio-Dryadion in Northern Scandinavia. Svensk Botanisk Tidskrift 49(1/2):63-87.

Ohba, T. 1974. Vergleichende Studien über die alpine Vegetation Japans. 1. Carici rupestris-Kobresietea bellardii. Phytocoenologia 1(3):331-401.

Pechnov, V.G. (ed.) 1977. Geomorphology of Karelia and Kola Peninsula. Nedra, Leningrad, 183 pp. (in Russian). [Teoморфология Карелии и Кольского полуострова / поА ред. Печнова В.Г. А.: изА-во «Недра», 1977. 183 с.].

Ramberg, B., I. Bryhni, A. Nottvedt \& K.Rangnes (eds.) 2008. The making of a land-geology of Norway. Norsk Geologisk Forening, Trondheim, 624 pp.

Rønning, O.I. 1965. Studies in Dryadion of Svalbard. Norsk Polarinstitutt Scrifter 134. 52 p.

Santesson, R., R. Moberg, A. Nordin, T. Tonsberg \& O. Vitikainen 2004. Lichen-forming and lichenicolous fungi of Fennoscandia. Uppsala, $359 \mathrm{pp}$

Telyatnikov, M.Y. 2003. Vegetation of typical tundras of Yamal Peninsula. Nauka, Novosibirsk, 122 pp. (in Russian). [TeАятников М.Ю. Растительность типичных тундр помуострова Ямац. Новосибирск: Наука, 2003. 122 с.].

Telyatnikov, M.Y. 2009. The syntaxonomic characteristics of the dwarf shrub-grass-moss-lichen tundra of the northwestern part of Putorana Plateau. Vestnik Novosibirskogo gosudarstvennogo universiteta. Seriya Biologia i klinicheskaya meditsina 7(4):16-21 (in Russian). [Телятников М.Ю. Синтаксономическая характеристика травяно-кустарничково-мохово-Аишайниковых тундр северо-запаАной части плато Путорана // Вестн. Новосиб. ун-та. Сер. Биология, клин. медицина. 2009. Т. 7, вып. 4. C. 16-21].

Telyatnikov M.Y. 2010 a. Syntaxonomy of the dwarf-shrub vegetation of the class Loiseleurio-Vaccinietea of the northwestern part of Putorana plateau. Vestnik Novosibirskogo gosudarstvennogo universiteta. Seriya Biologia $i$ klinicheskaya meditsina 8(3):166-174 (in Russian). [Телятников М.Ю. Синтаксономическая характеристика сообществ класcа Loiseleurio-Vaccinietea северо-западной части плато Путорана (классификация тундр плато Путорана) // Вестн. Новосиб. ун-та. Сер. Биология, клин. медицина. 2010 а. Т. 8, вып. 3. С. 166-174].

Telyatnikov, M.Y. 2010 b. Characteristics of syntaxa of the class Loiseleurio-Vaccinietea of the north-eastern part of the vicinities of Lake Pyasino (south-west of the north Siberian plain). Rastitel'nyi mir aziatskoi Rossii 1(5):33-41 (in Russian). [Телятников М.Ю. Характеристика синтаксонов класса Loiseleurio-Vaccinietea северо-восточной части окрестностей озера Пясино (юго-запаА Северо-Сибирской равнины) // Растительный мир Азиатской России. 2010 b. № 1(5). С. 33-41].
Telyatnikov, M.Y. 2011. Intrazonal vegetation of high mountains of the northwest part of Putorana Plateau. Rastitel'nyi mir aziatskoi Rossii 1:66-72 (in Russian). [Teмятников М.Ю. Интразональная растительность высокогорий северо-западной части плато Путорана / / Растительный мир Азиатской России. 2011. № 1. С. 66-72].

Telyatnikov, M.Y. \& S.A. Pristyazhnyuk 2012. The classification of subshrub and moss tundras on Yamal peninsula and adjacent areas. Vestnike Novosibirskogo gosudarstvennogo universiteta. Seriya Biologia i klinicheskaya meditsina 10(2): 56-64 (in Russian). [Темятников М.Ю., Пристяжнюк C.A. Классификация кустарничковых и моховых тунАр полуострова Ямал и прилегающих территорий // Вестн. Новосиб. гос. ун-та. Сер.: Биология, клин. медицина. 2012. Т. 10, вып. 2. С. 56-64].

Yurtsev, B.A., A.I. Tolmachev \& O.V. Rebristaya 1978. The floristic delimitation and subdivision of the Arctic. In: Arctic floristic region. (B.A. Yurtsev, ed.), pp. 9-104, Nauka, Leningrad (in Russian). [Юрцев Б.А., Толмачев А.И., Ребристая О.В. ФАористическое ограничение и разделение Арктики / / Арктическая флористическая область / под ред. Б.А. Юрцева. А.: Наука, 1978. C. 9-104].

Valachovič, M., K. Dierssen, P. Dimopoulos, E. Hadač, J. Loidi, L. Mucina, G. Rossi, F. V. Tendero \& M. Tomaselli 1997. The Vegetation on Screes: A Synopsis of Higher Syntaxa in Europe. Folia Geobotanica et Phytotaxonomica 32(2):173-192.

Virtanen, R., L. Oksanen \& V. Razzhivin 1999. Topographic and regional patterns of tundra heath vegetation from northern Fennoscandia to the Taimyr Peninsula. Acta Botanici Fennici 167: 29-83.

Vysotsky, G.N. 1927. Theses on soil and moisture. Lesovedenie i lesovodstvo. Sbornik Lesnogo obschestva v Leningrade 4: 65-79 (in Russian). [Высоцкий Г.Н. Тезисы о почве и влаге // Аесоведение и месоводство. Сборник месного общества в Аенинграде. 1927. Вып. 4. С. 65-79].

Weber, H.E., J. Moravec \& J.-P. Theurillat 2000. International code of phytosociological nomenclature. 3rd ed. Journal of Vegetation Science 11:739-768.

Westhoff, V. \& E. van der Maarel 1973. The Braun-Blanquet approach. In: Handbook of Vegetation Science, V. Ordination and classification of communities (R.H. Whittaker, ed.) pp. 617-626. Junk, The Hague.

Zoricheva, A.I. (ed.) 1963. Geology of the USSR. Vol. II. Arkhangel'sk, Vologda Regions and Komi ASSR. Part 1. Geological description. Nedra, Moscow, 1080 pp. (in Russian). ГГеология СССР. Том II. Архангельская, Вологодская области и Коми АССР. Часть 1. Геологическое описание / под реА. Зоричевой А.И. М.: изА-во «НеАpa», 1971. 1080 c.]. 